(c) American Dairy Science Association, 2005.

\title{
Varying Protein and Starch in the Diet of Dairy Cows. I. Effects on Ruminal Fermentation and Intestinal Supply of Nutrients
}

\author{
I. R. Ipharraguerre, ${ }^{1}$ J. H. Clark, ${ }^{1}$ and D. E. Freeman ${ }^{2}$ \\ ${ }^{1}$ Department of Animal Sciences, and \\ ${ }^{2}$ Department of Veterinary Clinical Medicine, University of Illinois, Urbana 61801
}

\begin{abstract}
The main objective of this experiment was to examine the effects of the percentage and source of crude protein (CP) and the amount of starch in the diet of dairy cows on ruminal fermentation, nutrient passage to the small intestine, and nutrient digestibility. For this purpose, 6 multiparous Holstein cows fistulated in the rumen and duodenum that averaged $73 \mathrm{~d}$ in milk were used in a $6 \times 6$ Latin square design with a $2 \times 3$ factorial arrangement of treatments. Two sources of $\mathrm{CP}$ [solventextracted soybean meal (SBM) and a mixture of SBM and a blend of animal-marine protein supplements plus ruminally protected Met (AMB)] and 3 levels of dietary protein (about 14, 16, and 18\%) were combined into 6 treatments. On a dry matter (DM) basis, diets contained $25 \%$ corn silage, $20 \%$ alfalfa silage, $10 \%$ cottonseed, 26.7 to $37 \%$ corn grain, and 4 to $13.5 \%$ protein supplement. Intakes and digestibilities in the rumen and total tract of DM, organic matter, acid and neutral detergent fiber were unaffected by treatments. Increasing dietary $\mathrm{CP}$ from 14 to $18 \%$ decreased the intake and apparent ruminal and total tract digestion of starch, but increased the proportion of starch consumed by the cows that was apparently digested in the small intestine. At 14\% CP, starch intake and total tract digestion were higher for the AMB diet than for the SBM diet, but the opposite occurred at $16 \% \mathrm{CP}$. Across CP sources, increasing CP in the diet from 14 to $18 \%$ increased the intakes of $\mathrm{N}$ and amino acids (AA), and ruminal outflows of nonammonia $\mathrm{N}$, nonammonia nonmicrobial $\mathrm{N}$, each individual AA except Met, total essential AA, and total AA. Across CP percentages, replacing a portion of SBM with AMB increased the intake of Met and Val and decreased the concentration of ammonia $\mathrm{N}$ in the rumen, but did not affect the intake of other essential AA or the intestinal supply of any essential AA and starch. The ruminal outflow of microbial $\mathrm{N}$, the proportional contribution of Lys and Met to total AA delivered to the duodenum,
\end{abstract}

Received October 22, 2004.

Accepted March 25, 2005.

Corresponding author: Ignacio R. Ipharraguerre; e-mail: ipharrag @uiuc.edu. and milk yield were unaffected by treatments. Data suggest that the intake of $\mathrm{N}$ by high-producing dairy cows that consume sufficient energy and other nutrients to meet their requirements can be decreased to about 600 to $650 \mathrm{~g}$ daily without compromising the supply of metabolizable protein if the source and amount of dietary $\mathrm{CP}$ and carbohydrate are properly matched.

(Key words: ruminal fermentation, intestinal supply of nutrients, dairy cow, protein)

Abbreviation key: AMB = blend of animal-marine protein supplements plus ruminally protected Met, EAA = essential amino acids, $\mathbf{H C P}=$ high $\mathrm{CP}, \mathbf{L C P}=$ low $\mathrm{CP}, \mathbf{M C P}=$ medium $\mathrm{CP}, \mathbf{M N}=$ microbial $\mathrm{N}, \mathbf{M P}=$ metabolizable protein, $\mathbf{N A N M N}=$ nonammonia nonmicrobial $\mathrm{N}, \mathbf{N E A A}=$ nonessential amino acids, $\mathbf{S B M}=$ solvent-extracted soybean meal.

\section{INTRODUCTION}

During the last few years, awareness regarding the potential contribution of intensive dairy farming to nitrogen pollution has escalated. As a result, research and modeling efforts have been conducted to identify management and nutritional strategies for reducing the excretion of $\mathrm{N}$ into the off-farm environment (e.g., Kohn et al., 1997; St-Pierre and Thraen, 1999; Jonker et al., 2002). Results from these studies suggest that improving the efficiency of $\mathrm{N}$ use by dairy cows, which in most production schemes rarely exceeds 25 to $30 \%$, is the most promising way to decrease $\mathrm{N}$ losses from dairy farms with minimal detrimental effects, if any, on their productivity and profitability. Reducing the output of $\mathrm{N}$ in urine provides the greatest opportunity for achieving that goal (Hvelplund and Madsen, 1996). This is because most of the $\mathrm{N}$ present in urine arises from inefficient $\mathrm{N}$ transactions in the rumen and peripheral tissues that may be amenable to manipulation (Lobley, 2002).

The supply of metabolizable protein (MP) to dairy cows mainly comprises proteins of microbial (MN) and feed origin that pass from the rumen and are absorbed as AA from the small intestine (NRC, 2001). To max- 
imize the efficiency of $\mathrm{N}$ use for milk production without compromising cow productivity, it is expected that first the supply of total AA in MP must be sufficient, but not excessive, for meeting maintenance and production needs of the cow. Second, a further improvement would be expected when the profile of absorbable essential AA (EAA) that reaches the small intestine exactly matches the demand of the cow for EAA. This additional benefit would be obtained because the efficiency with which AA are used for protein synthesis is maximized (Sloan, 1997; NRC, 2001).

These likely events are partly supported by recent studies that showed that reducing $\mathrm{N}$ intake while correcting for predicted shortages of limiting AA for milk production by including RUP supplements (Castillo et al., 2001; Noftsger and St-Pierre, 2003) and (or) rumenprotected AA (Kröber et al., 2000; Leonardi et al., 2003; Noftsger and St-Pierre, 2003) in the diet can reduce excretion of $\mathrm{N}$ in urine and sustain production of milk and milk protein. In these studies, dietary CP was reduced by replacing high-protein supplements with cereal grains, sources of nonforage fiber, or protein supplements lower in CP. In some cases, urea was added to the low CP diets to prevent limiting microbial growth because of a deficiency of RDP. Consequently, in these experiments the amount and form of $\mathrm{N}$ and carbohydrate available in the rumen and intestines might have differed between treatments. These factors and their interaction are major determinants of the ruminal outflow of MN and RUP (Clark et al., 1992), ruminal fermentation (Nocek and Russell, 1988), and, ultimately, the efficiency or pattern of use of absorbed nutrients for milk production (Oldham, 1984). In none of those studies, however, were the impact of treatments on ruminal fermentation and the intestinal supply of nutrients assessed. Therefore, it remains unclear whether the reported effects on $\mathrm{N}$ excretion and cow performance were achieved independently of alterations in ruminal metabolism and the postruminal supply of $\mathrm{N}$ and carbohydrate.

Recently, Bateman et al. (2001) reported that some of the most widely used models for predicting the supply of MP to dairy cows underestimated both the amount of feed CP and total CP that exited the rumen. These researchers explained their findings by proposing that the proportion of individual feed protein that is degraded in the rumen of dairy cows that consume large amounts of feed is less than that assumed by current feeding standards (Bateman et al., 2001). As follows, use of these models to examine the adequacy of diets for meeting the requirements of dairy cows for MP may contribute to overfeeding $\mathrm{N}$ and exacerbate its inefficient use for milk production. To solve this limitation, more data for the outflow of $\mathrm{N}$ fractions from the rumen of dairy cows that consume large quantities of feed is needed.

Two experiments were conducted concurrently to test the broad hypothesis that the CP content of the diet can be decreased to improve the efficiency of $\mathrm{N}$ use for milk production without affecting negatively the supply of MP and the lactational performance of dairy cows if the source and amount of CP are properly matched with the source and amount of carbohydrate in the diet. The objectives of the experiment were 1) to determine the effects of the amount and source of $\mathrm{CP}$ and the amount of starch in the diet of dairy cows on ruminal fermentation, passage of nutrients to the small intestine, and nutrient digestibility; 2 ) to relate differences in conversion of feed $\mathrm{N}$ to milk $\mathrm{N}$ and productivity of cows determined in a companion experiment (Ipharraguerre and Clark, 2005b) to alterations in ruminal fermentation, intestinal supply of nutrients, and use of nutrients by dairy cows; 3 ) and to examine the passage of $\mathrm{N}$ fractions to the small intestine of dairy cows that consume large quantities of diets supplemented with proteins reported to be high in either RDP or RUP.

\section{MATERIALS AND METHODS}

\section{Animals, Experimental Design, and Management}

Six multiparous Holstein cows that averaged 73 DIM (39 to $98 \mathrm{~d}$ ) at the onset of the experiment were surgically fitted with ruminal and duodenal cannulas according to procedures approved by the University of Illinois Laboratory Animal Care Advisory Committee. The ruminal cannulas were constructed of soft plastic (Bar Diamond, Parma, ID) and measured $10.2 \mathrm{~cm}$ in diameter. The duodenal cannulas were an enclosed Tshaped design made of stainless steel (Berzins Vet Laboratory Ltd., Edmonton, Alberta, Canada). They were placed proximal to the common bile and pancreatic duct, about $10 \mathrm{~cm}$ distal to the pylorus.

The experimental design was a $6 \times 6$ Latin square with a $2 \times 3$ factorial arrangement of treatments. Two protein supplements (source) of different ruminal degradability and 3 concentrations (percentage) of dietary protein were combined into the following treatments: 1) low CP (LCP), solvent-extracted soybean meal (SBM); 2) LCP, blend of animal-marine protein supplements (i.e., meals of blood, porcine meat and bone, menhaden fish, and hydrolyzed feather) plus ruminally protected Met (AMB); 3) medium CP (MCP), SBM; 4) MCP, AMB; 5) high CP (HCP), SBM; and 6) HCP, AMB. Diets were formulated to contain 14\% (LCP), $16 \%$ (MCP), or $18 \% \mathrm{CP}$ (HCP) by replacing an increasing proportion of corn with protein supplements as the $\mathrm{CP}$ content of the diet increased (Table 1). Consequently, the effects of the concentration of starch and protein in 
Table 1. Ingredient and chemical composition of the experimental $\operatorname{diets}^{1}$ (DM basis).

\begin{tabular}{|c|c|c|c|c|c|c|}
\hline \multirow[b]{2}{*}{ Item } & \multicolumn{2}{|c|}{ LCP } & \multicolumn{2}{|c|}{ MCP } & \multicolumn{2}{|c|}{$\mathrm{HCP}$} \\
\hline & SBM & AMB & SBM & AMB & SBM & AMB \\
\hline \multicolumn{7}{|l|}{ Ingredient } \\
\hline Alfalfa silage, $\%$ & 20.00 & 20.00 & 20.00 & 20.00 & 20.00 & 20.00 \\
\hline Corn silage, \% & 25.00 & 25.00 & 25.00 & 25.00 & 25.00 & 25.00 \\
\hline Cottonseed (w/lint), \% & 10.00 & 10.00 & 10.00 & 10.00 & 10.00 & 10.00 \\
\hline Ground shelled corn, \% & 36.42 & 37.01 & 30.80 & 34.01 & 26.65 & 30.67 \\
\hline Soybean meal ( $49 \%$ CP), \% & 4.75 & 2.33 & 9.13 & 4.48 & 13.50 & 6.62 \\
\hline Animal-marine protein blend, ${ }^{2} \%$ & $\ldots$ & 1.73 & & 3.32 & & 4.90 \\
\hline Soyhulls, \% & $\ldots$ & $\ldots$ & 1.50 & $\ldots$ & 1.50 & $\ldots$ \\
\hline Inert fat, ${ }^{3} \%$ & $\ldots$ & 0.36 & & & & \\
\hline Sodium bicarbonate, $\%$ & 1.00 & 1.00 & 1.00 & 1.00 & 1.00 & 1.00 \\
\hline Sodium chloride, $\%$ & 0.25 & 0.25 & 0.25 & 0.25 & 0.25 & 0.25 \\
\hline Mineral and vitamin $\operatorname{mix},{ }^{4} \%$ & 0.25 & 0.25 & 0.25 & 0.25 & 0.25 & 0.25 \\
\hline Dicalcium phosphate, $\%$ & 0.62 & 0.52 & 0.54 & 0.32 & 0.45 & 0.12 \\
\hline Limestone, \% & 1.08 & 0.93 & 1.07 & 0.95 & 1.10 & 0.94 \\
\hline Magnesium oxide, \% & 0.17 & 0.18 & 0.15 & 0.17 & 0.14 & 0.17 \\
\hline Sodium sulfate, $\%$ & 0.46 & 0.44 & 0.31 & 0.25 & 0.16 & 0.08 \\
\hline \multicolumn{7}{|l|}{ Chemical composition } \\
\hline $\mathrm{DM}, \%$ & 65.5 & 65.3 & 65.4 & 65.4 & 65.7 & 65.7 \\
\hline $\mathrm{OM}, \%$ & 93.4 & 93.5 & 93.3 & 93.6 & 93.4 & 93.5 \\
\hline $\mathrm{CP}, \%$ & 13.9 & 13.9 & 16.1 & 16.0 & 17.9 & 18.3 \\
\hline RUP, ${ }^{5} \%$ & 4.8 & 5.2 & 5.6 & 6.4 & 6.4 & 7.6 \\
\hline RUP, $5 \%$ of $\mathrm{CP}$ & 34.5 & 37.4 & 34.8 & 40.0 & 35.8 & 41.5 \\
\hline $\mathrm{RDP},{ }^{5} \%$ & 9.1 & 8.7 & 10.5 & 9.6 & 11.5 & 10.7 \\
\hline $\mathrm{NDF}, \%$ & 31.2 & 30.3 & 30.9 & 30.8 & 30.6 & 30.9 \\
\hline $\mathrm{ADF}, \%$ & 19.5 & 19.6 & 20.4 & 19.7 & 20.5 & 19.9 \\
\hline Starch, \% & 32.8 & 33.0 & 29.6 & 30.5 & 27.0 & 29.4 \\
\hline $\mathrm{NE}_{\mathrm{L}}, \mathrm{Mcal} / \mathrm{kg}$ of $\mathrm{DM}^{5}$ & 1.53 & 1.51 & 1.53 & 1.52 & 1.54 & 1.53 \\
\hline
\end{tabular}

\footnotetext{
${ }^{1} \mathrm{AMB}=$ Animal-marine protein blend, $\mathrm{HCP}$ = high $\mathrm{CP}$ diet, $\mathrm{LCP}=$ low $\mathrm{CP}$ diet, $\mathrm{MCP}=$ medium $\mathrm{CP}$ diet, $\mathrm{SBM}=$ solvent-extracted soybean meal.

${ }^{2}$ ProLak (H. J. Baker \& Bros., Inc., Westport, CT)

${ }^{3}$ Megalac (Church \& Dwight, Co., Inc., Princeton, NJ)

${ }^{4}$ Contained $5.0 \% \mathrm{Mg}, 7.5 \% \mathrm{~K}, 10.0 \% \mathrm{~S}, 3.0 \% \mathrm{Zn}, 3.0 \% \mathrm{Mn}, 2.0 \% \mathrm{Fe}, 0.5 \% \mathrm{Cu}, 0.025 \% \mathrm{I}, 0.015 \% \mathrm{Se}, 0.004 \%$ Co, $2200 \mathrm{IU}$ of vitamin $\mathrm{A} / \mathrm{g}, 660 \mathrm{IU}$ of vitamin $\mathrm{D}_{3} / \mathrm{g}$, and $8 \mathrm{IU}$ of vitamin $\mathrm{E} / \mathrm{g}$.

${ }^{5}$ Calculated using tabulated values from NRC (2001) and assuming an intake of 4 times maintenance. It was also assumed that $70 \%$ of the CP in ProLak is RUP.
}

the diet were confounded. The AMB supplement (ProLak; H. J. Baker \& Bros., Inc., Westport, CT) partially replaced SBM in the concentrate mixtures with the aim of enhancing the RUP content of the diets (Table 1). Our ultimate goal was to improve quantitatively and qualitatively the supply of MP at each concentration of dietary CP through increased input of digestible RUP with an AA composition balanced to complement microbial protein. The remaining dietary ingredients were supplied from the same source and in the amounts needed to meet the NRC (2001) nutrient requirements (Table 1). Each cow was randomly assigned to 1 of 6 treatment sequences in which a treatment never followed the same treatment for all sequences. Experimental periods lasted $14 \mathrm{~d}$; the first $9 \mathrm{~d}$ of each period were used to adapt the cows to treatments and the remaining $5 \mathrm{~d}$ were used to collect data.

Cows were fed diets as TMR for ad libitum intake to ensure $10 \%$ orts. The TMR were offered twice daily at 0600 and $1700 \mathrm{~h}$ and were adjusted weekly to reflect changes in DM of forages and concentrate mixtures by drying each component overnight in an oven at $105^{\circ} \mathrm{C}$. Cows were housed in individual stanchions equipped with water bowls and bedded with rubber mats and straw and were milked twice daily at 0600 and 1800 $h$. With the exception of the last $3 \mathrm{~d}$ of each period when samples were being collected, cows were allowed to exercise in a dry lot from 0800 to $0900 \mathrm{~h}$.

\section{Sampling, Measurements, and Analyses}

Dry matter intake and orts were measured and recorded daily. Samples of individual feed ingredients, TMR, and orts were collected for the last $5 \mathrm{~d}$ of each period. Samples of individual feedstuffs and TMR were dried at $55^{\circ} \mathrm{C}$ in an oven for $72 \mathrm{~h}$, ground through a 2mm screen in a Wiley mill (Arthur H. Thomas, Philadelphia, PA), composited on an equal weight basis by period, and ground through a 1-mm screen. Samples of orts were dried at $55^{\circ} \mathrm{C}$ in an oven for $72 \mathrm{~h}$, ground 
through a 2-mm screen, composited by the amount and dry weight of the daily orts for each cow, and ground through a 1-mm screen. Samples of feeds, TMR, and orts were analyzed for DM, OM, Kjeldahl N (AOAC, 1990), ADF (Van Soest et al., 1991), NDF with heatstable $\alpha$-amylase (Thermamyl 120L; Novo Nordisk Biochem, Franklinton, NC) and sodium sulfite (Van Soest et al., 1991), and starch (Kartchner and Theurer, 1981). Samples of feeds and TMR were prepared for AA determination, except Met, by acid hydrolysis with $6 \mathrm{~N} \mathrm{HCl}$ (McCarthy et al., 1989). For Met determination, samples were first oxidized with performic acid, lyophilized after dilution with water to remove excess performic acid (Overton et al., 1995), and hydrolyzed with $6 \mathrm{~N}$ $\mathrm{HCl}$ as outlined by Moore (1963). Individual AA were then separated by ion exchange chromatography on a Beckman 126AA amino acid analyzer equipped with a Beckman 12-cm column (Beckman Instruments Inc., Palo Alto, CA).

Samples of ruminal fluid and duodenal digesta were collected every $3 \mathrm{~h}$ during the last $3 \mathrm{~d}$ of each period. The sampling time was adjusted ahead $1 \mathrm{~h}$ daily so that a sample was obtained for each 1-h interval of the day (24 total samples). Ruminal fluid samples were taken from multiple sites in the rumen and $\mathrm{pH}$ of ruminal fluid was measured immediately by glass electrode. After measurement of $\mathrm{pH}$, a subsample of $50 \mathrm{~mL}$ was acidified to $\mathrm{pH}<2$ with $50 \% \mathrm{H}_{2} \mathrm{SO}_{4}$ ( $\mathrm{vol} / \mathrm{vol}$ ), centrifuged at $27,000 \times g$ for $10 \mathrm{~min}$ at $4^{\circ} \mathrm{C}$, and the supernatant was frozen at $-20^{\circ} \mathrm{C}$ for later analyses. Following removal of the cap of the duodenal cannula, accumulated digesta was discarded, and when the flow appeared normal, $500 \mathrm{~mL}$ of duodenal contents were collected. Samples were pooled by cow and stored frozen in 20 -L buckets at $-20^{\circ} \mathrm{C}$ until analyses.

Ruminal fluid samples taken at $0,1,2,3,5,7,9$, and $10 \mathrm{~h}$ after the morning feeding, and at $0,1,2,3,5,7$, 9,11 , and $12 \mathrm{~h}$ after the afternoon feeding (17 total samples) were thawed, centrifuged at $27,000 \times g$ for 20 min at $4{ }^{\circ} \mathrm{C}$, and an aliquot of $4 \mathrm{~mL}$ was diluted with $25 \%$ metaphosphoric acid (4:1 ratio). These subsamples were assayed with a gas chromatograph (model 5890 Series II; Hewlett-Packard, Avondale, PA) equipped with a 1.8-m glass column packed with $10 \%$ SP 1200/ $1 \% \mathrm{H}_{3} \mathrm{PO}_{4}$ on $80 / 100$ chromosorb W AW (Supelco Inc., 1975) to determine the concentration of VFA. Nitrogen was the carrier gas, and the temperature of the injection port and column was 175 and $125^{\circ} \mathrm{C}$, respectively. $\mathrm{Ru}-$ minal ammonia $\mathrm{N}$ was determined according to the procedures outlined by Chaney and Marbach (1962) as modified by Cotta and Russell (1982).

Duodenal samples were thawed and homogenized for 5 min using a propeller-type mixer set at high speed. During continuous stirring, a representative subsample
$(1000 \mathrm{~mL})$ of digesta was collected by vacuum. Samples then were poured into shallow pans, lyophilized, ground through a 1-mm screen, and analyzed for DM, OM, Kjeldahl N, ADF, NDF, starch, and AA as described above. The duodenal digesta concentration of $\mathrm{NH}_{3} \mathrm{~N}$ was determined by steam distillation with $\mathrm{MgO}$ (Bremner and Keeney, 1965), and purines, used as a bacterial marker, were measured by the method of Zinn and Owens (1986).

Ruminal bacteria were isolated from samples (1000 $\mathrm{mL}$ ) of whole ruminal contents obtained from the reticulum near the reticulo-omasal orifice at 6 separate postfeeding times $(0,2,4,6,8$, and $10 \mathrm{~h})$ during the last 3 $\mathrm{d}$ of each period. Ruminal contents were blended in a Waring blender (Waring Products Division, New Hartford, CT) for $1 \mathrm{~min}$ at low speed, strained through 6 layers of cheesecloth, and the effluents were used to prepare a bacteria-rich sample by differential centrifugation (Overton et al., 1995). Bacterial samples were pooled by cow within period and frozen at $-20^{\circ} \mathrm{C}$. These samples were lyophilized and analyzed for DM, OM, Kjeldahl N, AA, and purines by the methods described above.

During the last $6 \mathrm{~d}$ of each period, fecal grab samples were collected twice daily at 12 -h intervals. The sampling time was adjusted ahead $2 \mathrm{~h}$ daily so that a sample was obtained for each 2-h interval of the day (12 total samples). Samples were composited on an equal wet weight basis, dried at $55^{\circ} \mathrm{C}$, ground through a $1-\mathrm{mm}$ screen, and assayed for $\mathrm{DM}$, OM, Kjeldahl N, ADF, $\mathrm{NDF}$, and starch as described above.

Chromic oxide was used as an indigestible marker to assess the passage of digesta to the duodenum and fecal excretion by the cows. Gelatin capsules that contained $10 \mathrm{~g}$ of $\mathrm{Cr}_{2} \mathrm{O}_{3}$ powder were administered via the ruminal cannula at 0800 and $2000 \mathrm{~h}$ during the last $10 \mathrm{~d}$ of each period. Concentration of $\mathrm{Cr}$ in duodenal and fecal samples was quantified by atomic absorption spectroscopy (air plus acetylene flame; Perkin-Elmer, Norwalk, CT) after preparation of samples by the procedure of Williams et al. (1962).

Passage of MN and microbial OM to the duodenum was calculated from the passage of DM and from the proportion of $\mathrm{N}$ or $\mathrm{OM}$ of bacterial origin, respectively. These proportions were estimated by dividing the $\mathrm{N}$ to purine ratio or the OM to purine ratio of isolated bacteria by the $\mathrm{N}$ to purine ratio or the $\mathrm{OM}$ to purine ratio of duodenal digesta. Passage of nonammonia nonmicrobial N (NANMN) to the duodenum was calculated by subtracting passage of MN from passage of total NAN. Apparent digestibility of $\mathrm{OM}$ in the rumen was corrected for the passage of microbial OM to the duodenum to establish the amount of OM truly digested in the rumen. 
Milk weights were recorded at each milking throughout the last $7 \mathrm{~d}$ of each period. Milk samples were taken at each milking during the last $7 \mathrm{~d}$ of each period, preserved with 2-bromo-2-nitropropane-1,3-diol, and stored at $4^{\circ} \mathrm{C}$. Samples were sent to Dairy One Cooperative Inc. (Ithaca, NY) for analyses of fat, CP, true protein, total solids, and urea $\mathrm{N}$ by infrared procedures (AOAC, 1990; Foss 4000; Foss North America, Eden Prairie, MN).

\section{Statistical Analyses}

Data were analyzed as a $6 \times 6$ Latin square using the MIXED procedure of SAS (SAS Institute, 2000), with cow treated as a random variable and according to the following model:

$$
\mathrm{Y}_{\mathrm{ijk}}=\mu+\mathrm{C}_{\mathrm{i}}+\mathrm{P}_{\mathrm{j}}+\mathrm{L}_{\mathrm{k}}+\mathrm{S}_{\mathrm{l}}+\mathrm{LS}_{\mathrm{kl}}+\varepsilon_{\mathrm{ijk}}
$$

where $\mu$ = overall mean; $\mathrm{C}_{\mathrm{i}}=$ effect of cow $\mathrm{i}(\mathrm{i}=1,2,3$, $4,5,6) ; \mathrm{P}_{\mathrm{j}}=$ effect of period $\mathrm{j}(\mathrm{j}=1,2,3,4,5,6) ; \mathrm{L}_{\mathrm{k}}=$ effect of the $\mathrm{k}$ percentage of dietary $\mathrm{CP}(\mathrm{k}=1,2,3)$; $\mathrm{S}_{1}=$ effect of the 1 source of supplemental CP $(1=1,2)$; $\mathrm{LS}_{\mathrm{kl}}=$ effect of the interaction between the k percentage and 1 source of $\mathrm{CP}$; and $\varepsilon_{\mathrm{ijkl}}=$ residual error.

Least square means were separated into significant main effects by the PDIFF option of SAS (SAS Institute, 2000). Ruminal VFA, $\mathrm{NH}_{3} \mathrm{~N}$, and $\mathrm{pH}$ data were analyzed as repeated measures in time using the MIXED procedure of SAS (Littell et al., 1996). The smallest value for the Akaike's information criterion was used to select the most appropriate covariance structure (Littell et al., 1996). The model was similar to the model described previously except for the addition of the effect of hour and the interaction of treatment and hour. Because the treatment by hour interaction was not significant $(P>0.25)$ for the ruminal parameters measured, treatment effects were compared across treatment sampling times using the procedure described above.

Differences among treatments were considered significant when $P<0.05$, whereas when $P>0.05$ but $<$ 0.10 , differences were considered to indicate a trend toward a significant effect.

\section{RESULTS AND DISCUSSION}

\section{Chemical Composition of Diets and Feed Ingredients}

The percentage of $\mathrm{CP}$ in the diet ranged from 13.9 to 18.3 with minimal variation between protein sources within each percentage of dietary CP (Table 1). The AMB supplement provided 9.3, 15.6, and $20.1 \%$ of the dietary $\mathrm{CP}$ for the LCP, MCP, and HCP diets, respec- tively. Estimation of the RUP content of the diets as described in Table 1, indicated that the percentage of dietary DM supplied as RUP for the AMB diets was higher than that of the SBM diets at all concentrations of $\mathrm{CP}(0.4,0.8$, and 1.2 percentage units). For the AMB diets, the estimated proportion of dietary CP supplied as RUP increased by 2.6 and 1.5 percentage units when the CP content increased from 13.9 to 16.0 and 18.3, respectively. These increases were 0.3 and 1.0 percentage units for the SBM diets. As intended, the starch content declined as the percentage of $\mathrm{CP}$ increased and this effect was less pronounced for the AMB diets. The concentration of DM, OM, ADF, NDF, and energy (i.e., $\mathrm{NE}_{\mathrm{L}}$ ) remained constant across percentages and sources of CP.

Compared with SBM, the AMB product contained more CP per unit of DM with higher mean concentrations of His, Leu, Lys, Met, Thr, Phe, and Val (Table 2 ). The chemical composition of the protein supplements and other feed ingredients was within the range reported elsewhere (Beede et al., 1994; Degussa Corp., 2001; NRC, 2001).

\section{Intakes and Digestibilities of DM and OM}

The intakes of DM and OM were not affected by the percentage and source of dietary $\mathrm{CP}$, although they tended to be influenced by the interaction between percentage and source of $\mathrm{CP}$ (Table 3 ). For the MCP diets, cows fed SBM tended to consume more DM $(+1.4 \mathrm{~kg} / \mathrm{d})$ and $\mathrm{OM}(+1.2 \mathrm{~kg} / \mathrm{d})$ than those fed ABM, but the opposite was observed for the LCP diets $(-1.6$ and $-1.5 \mathrm{~kg} /$ $\mathrm{d}$, respectively). In the companion experiment (Ipharraguerre and Clark, 2005b), differences in DMI during the first $210 \mathrm{~d}$ of lactation were also small and not significant across percentages and sources of dietary CP. However, a significant $(P<0.002)$ interaction for DMI was detected because the HCP diet containing SBM resulted in greater DMI $(+2.5 \mathrm{~kg} / \mathrm{d})$ than the diet containing AMB. These results are in general agreement with results showing that the replacement of SBM with RUP supplements of marine and (or) animal origin can depress, but rarely increase, DMI (Santos et al., 1998; Ipharraguerre and Clark, 2005a), and that variability in this response is in part dictated by the percentage of dietary CP (Ipharraguerre, 2004; Ipharraguerre and Clark, 2005a). Likewise, results agree with previous data indicating that decreasing the $\mathrm{CP}$ content of the diet of lactating dairy cows generally has minor effects on DMI unless dietary CP is reduced to extremely low percentages ( $\leq 12 \%$; Allen, 2000 ; Ipharraguerre, 2004).

The amount and proportion of DM apparently digested in the total tract were unaffected by the percent- 
Table 2. Chemical composition of feed ingredients (DM basis).

\begin{tabular}{|c|c|c|c|c|c|c|}
\hline \multirow[b]{2}{*}{ Item } & \multicolumn{2}{|c|}{ Silages } & \multicolumn{4}{|c|}{ Energy and protein supplements ${ }^{1}$} \\
\hline & Alfalfa & Corn & Corn grain & Cottonseed & SBM & $\mathrm{AMB}$ \\
\hline OM, \% & 91.0 & 95.9 & 98.9 & 96.5 & 93.1 & 87.2 \\
\hline NDF, $\%$ & 47.0 & 38.8 & $\mathrm{ND}^{2}$ & 48.4 & 8.8 & ND \\
\hline $\mathrm{ADF}, \%$ & 38.5 & 24.9 & ND & 40.1 & 5.1 & ND \\
\hline Starch, \% & 0.8 & 28.1 & 64.8 & 0.3 & ND & ND \\
\hline $\mathrm{CP}, \%$ & 20.1 & 7.9 & 8.4 & 23.1 & 52.0 & 75.0 \\
\hline \multicolumn{7}{|c|}{$\mathrm{EAA},{ }^{3} \%$ of $\mathrm{CP}$} \\
\hline Arg & 3.08 & 2.09 & ND & ND & 7.35 & 6.37 \\
\hline His & 1.36 & 1.67 & ND & ND & 2.73 & 3.54 \\
\hline Ile & 4.10 & 3.42 & ND & ND & 5.12 & 3.43 \\
\hline Leu & 6.45 & 8.78 & ND & ND & 7.85 & 9.06 \\
\hline Lys & 3.93 & 2.38 & ND & ND & 7.06 & 7.23 \\
\hline Met & 1.70 & 2.08 & ND & ND & 1.29 & 1.57 \\
\hline Phe & 4.20 & 3.62 & ND & ND & 5.25 & 5.37 \\
\hline Thr & 3.86 & 2.99 & ND & ND & 4.40 & 4.68 \\
\hline Val & 5.22 & 4.54 & ND & ND & 5.35 & 7.32 \\
\hline
\end{tabular}

${ }^{1} \mathrm{AMB}=$ Animal-marine protein blend, $\mathrm{SBM}=$ solvent-extracted soybean meal.

${ }^{2} \mathrm{ND}=$ Not determined.

${ }^{3} \mathrm{EAA}=$ Essential amino acids.

age and source of dietary CP (Table 3). Similarly, the amount and proportion of OM apparently digested in the rumen and total tract and the amount of OM that passed to and was digested in the small intestine were not different among treatments. Several researchers also reported that varying the CP content of SBM-based diets within a range wider (11.3 to $19.9 \%$ ) than the one used in the experiment (13.9 to 18.3\%) had no effects on the extent and site of OM digestion (Klusmeyer et al., 1990; Christensen et al., 1993; Cunningham et al., 1996). Likewise, in a number of trials those parameters were not altered by the replacement of SBM with RUP

Table 3. Least square means for intakes and digestibilities of DM and OM in various segments of the gastrointestinal tract of lactating dairy cows fed diets containing different percentages and sources of CP. ${ }^{1}$

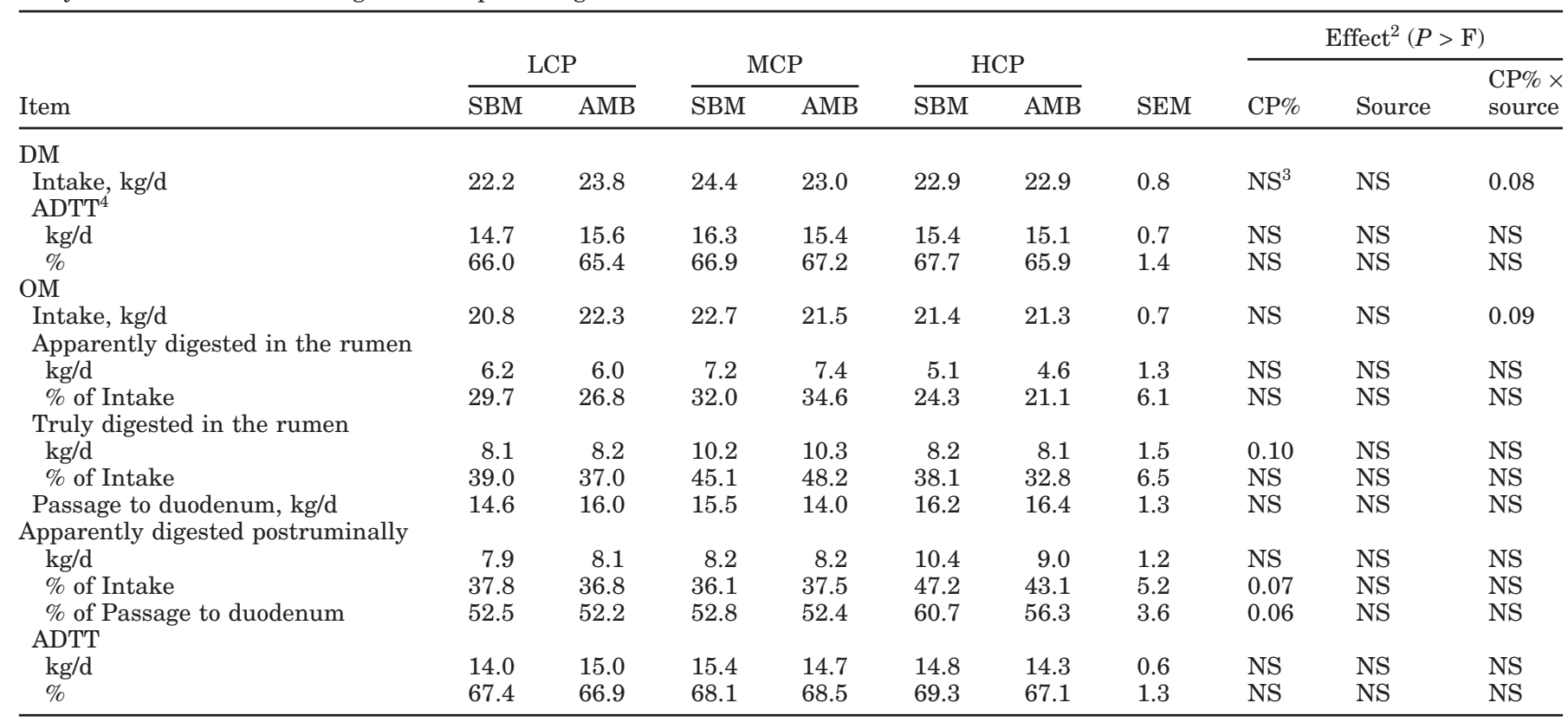

${ }^{1} \mathrm{AMB}=$ Animal-marine protein blend, $\mathrm{HCP}=$ high $\mathrm{CP}$ diet, $\mathrm{LCP}=$ low $\mathrm{CP}$ diet, $\mathrm{MCP}=$ medium $\mathrm{CP}$ diet, $\mathrm{SBM}=$ soybean meal.

${ }^{2} \mathrm{CP} \%=$ Percentage of $\mathrm{CP}$, Source $=$ source of $\mathrm{CP}, \mathrm{CP} \% \times$ source $=$ interaction between percentage and source of $\mathrm{CP}$.

${ }^{3}$ Nonsignificant $(P>0.10)$.

${ }^{4} \mathrm{ADTT}=$ Apparently digested in the total gastrointestinal tract. 
Table 4. Least square means for intakes and digestibilities of ADF, NDF, and starch in various segments of the gastrointestinal tract of lactating dairy cows fed diets containing different percentages and sources of $\mathrm{CP} .^{1}$

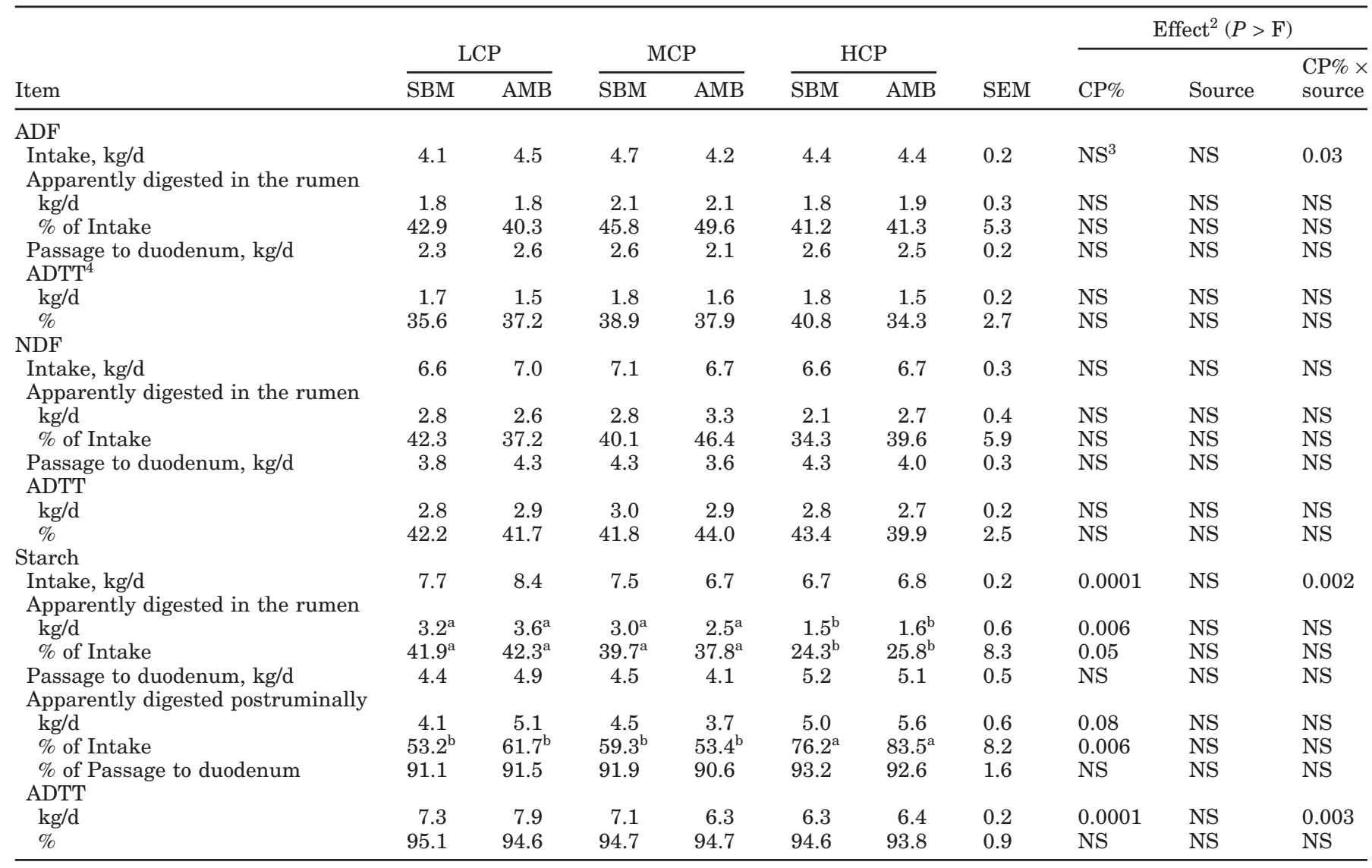

${ }^{\mathrm{a}, \mathrm{b}}$ Means within a row with different superscript differ significantly for the main effect of CP percentage. Pairwise comparisons were calculated using the appropriate standard error.

${ }^{1} \mathrm{AMB}=$ Animal-marine protein blend, $\mathrm{HCP}=$ high $\mathrm{CP}$ diet, $\mathrm{LCP}=$ low $\mathrm{CP}$ diet, $\mathrm{MCP}=$ medium $\mathrm{CP}$ diet, $\mathrm{SBM}=\mathrm{soybean}$ meal.

${ }^{2} \mathrm{CP} \%=$ Percentage of $\mathrm{CP}$, Source $=$ source of $\mathrm{CP}, \mathrm{CP} \% \times$ source $=$ interaction between percentage and source of $\mathrm{CP}$.

${ }^{3}$ Nonsignificant $(P>0.10)$.

${ }^{4} \mathrm{ADTT}=$ Apparently digested in the total gastrointestinal tract.

supplements of animal, marine, and (or) plant origin (Waltz et al., 1989; Christensen et al., 1993; Cunningham et al., 1994). Compared with the LCP and HCP diets, however, the amount of OM truly digested in the rumen tended to be greater for the MCP diet. Because true digestibility of OM did not change significantly, this trend might have been caused by the slightly greater intake of OM $(\sim 0.7 \mathrm{~kg} / \mathrm{d})$ by cows fed the MCP diet. A positive relationship between the intake and true digestibility of $\mathrm{OM}$ in the rumen of dairy cows has been shown previously (Clark et al., 1992). Compared with the LCP and MCP diets, cows fed HCP diets tended to have higher postruminal digestibility of OM (expressed as percentage of intake and passage to duodenum). As discussed later, this trend might have resulted from a proportionally higher contribution of digestible starch and protein to the ruminal outflow of $\mathrm{OM}$ for cows fed HCP diets. Improvements in the intestinal digestibility of OM were reported when urea was used to increase the CP content of diets supplemented with fish meal (Cameron et al., 1991), but such a response was not observed when the percentage of dietary $\mathrm{CP}$ of SBM-based diets was increased through addition of true protein supplements (Klusmeyer et al., 1990; Christensen et al., 1993).

\section{Intakes and Digestibilities of Carbohydrates}

Intakes, apparent ruminal and total tract digestibilities (amount and percentage), and flows to duodenum of ADF and NDF were not altered by treatments (Table 4). Although the amount (Cunningham et al., 1996) or source (Reynal and Broderick, 2003) of dietary CP influenced fiber digestibility in some studies, most frequently manipulation of these factors in the diet of lactating cows did not impact the extent and site of 
fiber digestion (Stern et al., 1983; Klusmeyer et al., 1990; Stokes et al., 1991; Christensen et al., 1993; Chan et al., 1997).

When the concentration of dietary $\mathrm{CP}$ increased from LCP to HCP, the intake of starch decreased on average from 8.0 to $6.7 \mathrm{~kg} / \mathrm{d}$. However, cows fed AMB consumed $0.7 \mathrm{~kg} / \mathrm{d}$ more starch than those fed SBM when diets contained LCP, whereas cows fed SBM consumed 0.8 $\mathrm{kg} / \mathrm{d}$ more starch than those fed AMB when diets contained MCP (Table 4). These differences arose from variations in both DMI (Table 3) and chemical composition of experimental diets (Table 1).

The percentage of dietary $\mathrm{CP}$, but not the source or interaction of these 2 factors, influenced the digestion of starch in the rumen and intestines (Table 4). As CP increased in the diet from LCP to HCP, the amount and percentage of starch apparently digested in the rumen decreased on average $1.8 \mathrm{~kg} / \mathrm{d}(53 \%)$ and 17 percentage units $(40.5 \%)$, respectively. This difference in ruminal starch digestibility compensated for the differences in starch intake, resulting in similar ruminal outflows of starch among treatments. However, as the dietary CP content increased, a slightly $(P<0.08)$ larger amount $($ mean $=0.7 \mathrm{~kg} / \mathrm{d})$, but a significantly larger proportion of the starch consumed by the cows (mean = 22.4 percentage units or $39 \%$ ) was digested in the intestines. Consequently, the percentage of starch apparently digested in the total tract was unaffected by treatments, but the quantity digested paralleled intake. Voelker and Allen (2003) also observed that reducing starch intake from 8.2 to $6.4 \mathrm{~kg} / \mathrm{d}$ by replacing corn grain with beet pulp to supply $12 \%$ of dietary DM decreased the amount and proportion of starch apparently digested in the rumen by $1.9 \mathrm{~kg} / \mathrm{d}$ and 16 percentage units $(38.1 \%)$, respectively. In turn, the percentage of starch intake that was digested in the intestines increased 16.9 percentage units (37\%), whereas its total tract digestibility remained unaltered by treatments. Other researchers reported similar relationships between the intake and the ruminal and postruminal digestion of starch in dairy cows (Cameron et al., 1991; Oba and Allen, 2003). Likewise, ruminal and postruminal digestibilities of starch were similar to values previously reported for diets that contained equivalent concentrations of starch (Cameron et al., 1991; Lynch et al., 1991; Reynolds et al., 1997; Voelker and Allen, 2003), in which corn grain and corn silage were the predominant source of starch. To our knowledge, few studies with dairy cows have evaluated the factorial effects of the percentage and source of $\mathrm{CP}$ on starch digestibility. Increasing dietary $\mathrm{CP}$ through additions of urea (Cameron et al., 1991) or a mix of RUP supplements plus urea (Christensen et al., 1993) did not affect the extent, percentage, or site of starch digestion.
The composition of the prevalent microbial population, or its pattern of metabolism, is at least one factor that might explain why there were differences in digestibility and site of starch digestion. As the concentration of $\mathrm{CP}$ in the diet increased and that of starch decreased, it is likely that nonstructural carbohydrate-fermenting bacteria declined whereas protein-, peptide-, and AAfermenting bacteria proliferated, comprising a significant proportion of the microbial population inhabiting the rumen. As a result, proportionally more digestible starch escaped ruminal fermentation and reached the duodenum. This hypothesis is supported in part by recent data from experiments in which the effects of feeding dairy cows diets with a variable nonstructural carbohydrate content on proteolytic bacteria were evaluated (Reilly et al., 2002). Populations of Prevotella and total Eubacteria were not affected by changes in the diet, but the numbers of Butyrivibrio increased, and the numbers of Eubacterium spp. decreased when carbohydrate was supplemented. Additionally, evidence is mounting that bacterial species that ferment peptides and AA as energy sources (e.g., Peptostreptococcus anaerobiu, Clostridium sticklandi, Clostridium aminophilum spp. nov., Eubacterium pyruvovarans spp. nov.) are commonly present in the rumen under numerous conditions (Attwood et al., 1998; Morrison, 2000). Most of these protein-, peptide-, and AA-degrading bacteria either do not use or poorly ferment carbohydrate, in particular starch, and predominantly produce long- and branched-chain organic acids such as butyrate, isobutyrate, valerate, isovalerate, and caproate as well as $\mathrm{NH}_{3} \mathrm{~N}$ (Hungate, 1966; Attwood et al., 1998). As is discussed in the next section, changes in ruminal $\mathrm{pH}$, molar proportions of VFA, and concentration of $\mathrm{NH}_{3} \mathrm{~N}(\mathrm{Ta}-$ ble 5) in response to higher inputs of dietary CP corresponded to such a pattern of fermentation, supporting further the above hypothesis.

Interestingly, the amount of starch digested in the intestines was positively correlated with the passage of NAN to duodenum:

$$
\begin{gathered}
\mathrm{Y}=0.008 \mathrm{X}(\mathrm{SE} 0.02, P<0.0001) \\
-0.108(\mathrm{SE} 1.09, P<0.92) ;\left(\mathrm{n}=30 ; \mathrm{R}^{2}=0.41\right)
\end{gathered}
$$

where $\mathrm{Y}=$ apparent postruminal digestion of starch $(\mathrm{kg} / \mathrm{d})$ and $\mathrm{X}=$ intestinal supply of NAN $(\mathrm{g} / \mathrm{d})$. The proportion of starch consumed by the cows that was digested in the intestines also was related, although only slightly $\left(\mathrm{R}^{2}=0.26\right)$, to the ruminal outflow of NAN. Because cows were not cannulated in the ileum, it is not possible to establish if these relationships indicate that increased intestinal supply of NAN (protein) improved the digestion of starch (i.e., quantity) in the small intestines and subsequently the supply of glucose 
Table 5. Least square means for ruminal fermentation parameters of lactating dairy cows fed diets containing different percentages and sources of CP. ${ }^{1}$

\begin{tabular}{|c|c|c|c|c|c|c|c|c|c|c|}
\hline \multirow[b]{3}{*}{ Item } & \multirow{2}{*}{\multicolumn{2}{|c|}{ LCP }} & \multirow{2}{*}{\multicolumn{2}{|c|}{ MCP }} & \multirow{2}{*}{\multicolumn{2}{|c|}{$\mathrm{HCP}$}} & \multirow[b]{3}{*}{ SEM } & \multicolumn{3}{|c|}{$\operatorname{Effect}^{2}(P>\mathrm{F})$} \\
\hline & & & & & & & & & & $\mathrm{CP} \% \times$ \\
\hline & SBM & $\mathrm{AMB}$ & SBM & AMB & SBM & $\mathrm{AMB}$ & & $\mathrm{CP} \%$ & Source & source \\
\hline Total VFA, mM & $122.6^{\mathrm{b}}$ & $123.1^{\mathrm{b}}$ & $129.1^{\mathrm{a}}$ & $124.6^{\mathrm{a}}$ & $128.0^{\mathrm{a}}$ & $126.1^{\mathrm{a}}$ & 2.04 & 0.05 & NS & NS \\
\hline Acetate, $\mathrm{mol} / 100 \mathrm{~mol}$ & 63.6 & 65.2 & 64.0 & 64.9 & 63.9 & 64.3 & 0.64 & NS & 0.006 & NS \\
\hline Propionate, mol/100 mol & 22.8 & 21.7 & 21.6 & 21.6 & 21.0 & 21.1 & 0.65 & NS & NS & NS \\
\hline Isobutyrate, $\mathrm{mol} / 100 \mathrm{~mol}$ & $0.7^{\mathrm{c}}$ & $0.7^{\mathrm{c}}$ & $0.8^{\mathrm{b}}$ & $0.8^{\mathrm{b}}$ & $0.9^{\mathrm{a}}$ & $0.9^{\mathrm{a}}$ & 0.03 & 0.0001 & NS & NS \\
\hline Valerate, mol/100 mol & $1.6^{\mathrm{b}}$ & $1.2^{\mathrm{b}}$ & $1.5^{\mathrm{b}}$ & $1.3^{\mathrm{b}}$ & $1.7^{\mathrm{a}}$ & $1.5^{\mathrm{a}}$ & 0.15 & 0.06 & 0.008 & NS \\
\hline $\mathrm{NH}_{3} \mathrm{~N}, \mathrm{mg} / \mathrm{dL}$ & $11.9^{\mathrm{c}}$ & $10.3^{\mathrm{c}}$ & $17.2^{\mathrm{b}}$ & $15.1^{\mathrm{b}}$ & $20.2^{\mathrm{a}}$ & $18.8^{\mathrm{a}}$ & 1.16 & 0.0001 & 0.02 & NS \\
\hline
\end{tabular}

a,b,c Means within a row with different superscript differ significantly for the main effect of CP percentage. Pairwise comparisons were calculated using the appropriate standard error.

${ }^{1} \mathrm{AMB}=$ Animal-marine protein blend, $\mathrm{HCP}=$ high $\mathrm{CP}$ diet, $\mathrm{LCP}=$ low $\mathrm{CP}$ diet, $\mathrm{MCP}=$ medium $\mathrm{CP}$ diet, $\mathrm{SBM}=\mathrm{soybean}$ meal.

${ }^{2} \mathrm{CP} \%=$ Percentage of $\mathrm{CP}$, Source $=$ source of $\mathrm{CP}, \mathrm{CP} \% \times$ source $=$ interaction between percentage and source of $\mathrm{CP}$.

${ }^{3}$ Nonsignificant $(P>0.10)$.

to the cows. However, if those positive correlations arose from enhanced cecal fermentation of starch rather than digestion in the small intestines, a decline in the intestinal or total tract digestibility of $\mathrm{N}$ would have occurred because of synthesis of microbial protein that could not be digested and absorbed from that segment of the digestive tract (Ørskov, 1992). As will be discussed later, this was not the case when the percentage of $\mathrm{CP}$ increased in the diet. A stimulatory effect of protein on the intestinal disappearance of starch or nonstructural carbohydrate has been observed in experiments with steers (Richards et al., 2002) and dairy cows (Abramson et al., 2002) infused abomasally with starch and casein. The relevance of this interaction between protein and carbohydrate resides in the beneficial effects that improved postruminal digestion of starch could have in the efficiency of use of energy (Huntington, 1997) and N (Oldham, 1984) for milk production. Therefore, results suggest that generalizations about the effects of the percentage and source of CP on performance of cows and (or) efficiency of nutrient use for milk production without considering the protein-carbohydrate interaction may be misleading.

\section{Ruminal Fermentation}

The interaction between the percentage and source of dietary CP for the ruminal fermentation parameters examined in this experiment was not significant (Table 5 ). These 2 factors, however, independently altered ruminal metabolism. Mean ruminal $\mathrm{pH}$ increased from 5.90 to 5.98 as the percentage of dietary CP increased from LCP to HCP, but differences were not significant between LCP and MCP. This response might be explained by the progressive decrease in the amount of starch digested in the rumen that resulted from the increase of $\mathrm{CP}$ in the diet (Table 4). Alternatively, the increase in ruminal $\mathrm{NH}_{3} \mathrm{~N}$ concentration that was associated with the increasing input of dietary $\mathrm{CP}$ might have contributed to buffer the acidity of the ruminal fluid. In previous experiments, varying the $\mathrm{CP}$ content of the diet of dairy cows did not affect ruminal $\mathrm{pH}$ (Klusmeyer et al., 1990; Christensen et al., 1993; Cunningham et al., 1996). The concentration of VFA in the ruminal fluid was higher for HCP and MCP than for $\mathrm{LCP}$, which is in contrast with changes in ruminal $\mathrm{pH}$. However, the ruminal concentration of VFA is the net result of production and absorption (Owens and Goetsch, 1988) and the rate of absorption increases as ruminal $\mathrm{pH}$ decreases (Merchen, 1988). Therefore, it is possible that differences detected for the concentration of VFA arose from a faster rate of removal of VFA from the rumen of cows fed LCP. More importantly, these differences were small and probably were not biologically relevant.

The molar proportions of acetate and propionate were not affected by the percentage of dietary CP. In contrast, the molar proportions of butyrate $(P<0.06)$, isobutyrate, valerate $(P<0.06)$, and isovalerate were increased by the HCP diet. Except for butyrate, these VFA originate from oxidative deamination and decarboxylation of branched-chain AA (Allison, 1978; Andries et al., 1987) and this along with the increase in ruminal $\mathrm{NH}_{3} \mathrm{~N}$ concentration, suggest that additional true protein was degraded in the rumen as the input of CP increased from LCP to HCP. In other experiments with dairy cows, increasing the $\mathrm{CP}$ content of the diet consistently enhanced the concentration of $\mathrm{NH}_{3} \mathrm{~N}$ in the rumen but not the molar proportions of branchedchain VFA (Klusmeyer et al., 1990; Christensen et al., 
Table 6. Least square means for intake and digestibility of $\mathrm{N}$ in various segments of the gastrointestinal tract of lactating dairy cows fed diets containing different percentages and sources of CP. ${ }^{1}$

\begin{tabular}{|c|c|c|c|c|c|c|c|c|c|c|}
\hline \multirow[b]{3}{*}{ Item } & \multirow{2}{*}{\multicolumn{2}{|c|}{$\mathrm{LCP}$}} & \multirow{2}{*}{\multicolumn{2}{|c|}{$\mathrm{MCP}$}} & \multirow{2}{*}{\multicolumn{2}{|c|}{$\mathrm{HCP}$}} & \multirow[b]{3}{*}{ SEM } & \multicolumn{3}{|c|}{ Effect $^{2}(P>\mathrm{F})$} \\
\hline & & & & & & & & \multirow[b]{2}{*}{$\mathrm{CP} \%$} & \multirow[b]{2}{*}{ Source } & \multirow{2}{*}{$\begin{array}{l}\mathrm{CP} \% \\
\text { source }\end{array}$} \\
\hline & $\mathrm{SBM}$ & AMB & SBM & AMB & SBM & $\mathrm{AMB}$ & & & & \\
\hline \multicolumn{11}{|l|}{ Passage to duodenum } \\
\hline Total N, g/d & 510 & 611 & 580 & 544 & 638 & 653 & 48.8 & 0.10 & NS & NS \\
\hline Total N, \% of N intake & $103.7^{\mathrm{b}}$ & $110.4^{\mathrm{b}}$ & $91.3^{\mathrm{a}}$ & $92.1^{\mathrm{a}}$ & $96.1^{\mathrm{ab}}$ & $98.8^{\mathrm{ab}}$ & 6.7 & 0.04 & NS & NS \\
\hline $\mathrm{NAN}, \mathrm{g} / \mathrm{d}$ & $488^{\mathrm{b}}$ & $555^{\mathrm{b}}$ & $554^{\text {ab }}$ & $518^{\mathrm{ab}}$ & $608^{\mathrm{a}}$ & $626^{\mathrm{a}}$ & 41.0 & 0.03 & NS & NS \\
\hline NANMN, $\%$ of NAN & $45.4^{\mathrm{b}}$ & $40.1^{\mathrm{b}}$ & $49.1^{\mathrm{b}}$ & $48.7^{\mathrm{b}}$ & $56.4^{\mathrm{a}}$ & $61.5^{\mathrm{a}}$ & 5.0 & 0.003 & NS & NS \\
\hline NANMN, \% of $\mathrm{N}$ intake & 45.8 & 43.6 & 43.2 & 43.5 & 51.4 & 58.2 & 6.0 & 0.10 & NS & NS \\
\hline Microbial N, g/d & 267 & 292 & 278 & 266 & 267 & 251 & 23.7 & NS & NS & NS \\
\hline Microbial N, \% of NAN & $54.6^{\mathrm{a}}$ & $59.9^{\mathrm{a}}$ & $50.9^{\mathrm{a}}$ & $51.3^{\mathrm{a}}$ & $43.6^{\mathrm{b}}$ & $38.4^{\mathrm{b}}$ & 5.0 & 0.002 & NS & NS \\
\hline Microbial N, g/kg of OMAD ${ }^{5}$ & 34.9 & 46.3 & 42.5 & 38.6 & 48.4 & 41.2 & 8.7 & NS & NS & NS \\
\hline Microbial N, g/kg of OMTD ${ }^{6}$ & 26.8 & 37.4 & 28.5 & 27.5 & 32.9 & 26.8 & 5.4 & NS & NS & NS \\
\hline Microbial N, g/kg of OMADTT ${ }^{7}$ & 19.2 & 20.0 & 18.0 & 18.3 & 18.0 & 16.4 & 1.6 & NS & NS & NS \\
\hline $\mathrm{g} / \mathrm{d}$ & $324^{\mathrm{c}}$ & $328^{\mathrm{c}}$ & $438^{\mathrm{b}}$ & $401^{\mathrm{b}}$ & $471^{\mathrm{a}}$ & $468^{\mathrm{a}}$ & 22.1 & 0.0001 & NS & NS \\
\hline$\%$ & $65.2^{\mathrm{b}}$ & $62.0^{\mathrm{b}}$ & $68.9^{\mathrm{a}}$ & $67.9^{\mathrm{a}}$ & $71.4^{\mathrm{a}}$ & $69.5^{\mathrm{a}}$ & 1.8 & 0.003 & 0.08 & NS \\
\hline
\end{tabular}

${ }^{a, b, c}$ Means within a row with different superscript differ significantly for the main effect of CP percentage. Pairwise comparisons were calculated using the appropriate standard error.

${ }^{1} \mathrm{AMB}=$ Animal-marine protein blend, $\mathrm{HCP}=$ high $\mathrm{CP}$ diet, $\mathrm{LCP}=$ low $\mathrm{CP}$ diet, $\mathrm{MCP}=$ medium $\mathrm{CP}$ diet, $\mathrm{SBM}=\mathrm{soybean}$ meal.

${ }^{2} \mathrm{CP} \%=$ Percentage of $\mathrm{CP}$, Source $=$ source of $\mathrm{CP}, \mathrm{CP} \% \times$ source $=$ interaction between percentage and source of $\mathrm{CP}$.

${ }^{3}$ Nonsignificant $(P>0.10)$.

${ }^{4} \mathrm{NANMN}=$ Nonammonia nonmicrobial N.

${ }^{5} \mathrm{OMAD}=$ Organic matter apparently digested in the rumen.

${ }^{6}$ OMTD $=$ Organic matter truly digested in the rumen .

${ }^{7}$ OMADTT = Organic matter apparently digested in the total gastrointestinal tract.

${ }^{8} \mathrm{ADTT}=$ Apparently digested in the total gastrointestinal tract.

1993; Cunningham et al., 1996). However, feeding increasing amounts of CP to sheep decreased the intake and amount of starch digested in the rumen and increased both the ruminal concentration of $\mathrm{NH}_{3} \mathrm{~N}$ and molar proportion of valerate and isovalerate (Ludden et al., 2002).

Compared with AMB, feeding SBM decreased ruminal $\mathrm{pH}$ and the molar proportion of acetate but increased the molar percentages of butyrate $(P<0.09)$ and valerate and the concentration of $\mathrm{NH}_{3} \mathrm{~N}$ in the ruminal fluid (Table 5). Because the intake and ruminal fermentation of $\mathrm{OM}$ and carbohydrates were not affected by the source of CP, these differences were likely caused by a more rapid rate of degradation of $\mathrm{OM}$ and protein in SBM than in AMB. Replacing SBM with RUP supplements of diverse origin, including meals of blood, fish, feather, meat, corn gluten, and soybeans, led to similar shifts in ruminal fermentation in some studies (Waltz et al., 1989; Christensen et al., 1993; Mansfield and Stern, 1994) but not in others (Cunningham et al., 1996; O'Mara et al., 1998; Reynal and Broderick, 2003). In all these studies, however, feeding RUP supplements consistently decreased the concentration of $\mathrm{NH}_{3} \mathrm{~N}$ in the ruminal fluid compared with SBM.

\section{Intake and Ruminal Outflow of Nitrogen}

The effects of the source of $\mathrm{CP}$ and the interaction between the percentage and source of $\mathrm{CP}$ were not significant for $\mathrm{N}$ intake, ruminal outflow of $\mathrm{N}$ fractions, and $\mathrm{N}$ digestibility in the intestines and total tract (Table 6). In a summary of studies, Santos et al. (1998) indicated that replacing SBM with RUP supplements in 25 treatment comparisons did not increase the intake of $\mathrm{N}$. In contrast to results reported here, a meta-analytic review of studies designed to examine the impact of RUP supplements on the outflow of $\mathrm{N}$ fractions from the rumen of dairy cows (Ipharraguerre and Clark, $2005 \mathrm{~b})$ showed that the intestinal supply of NAN and NANMN was significantly $(P<0.05)$ increased (mean $=$ 6.2 and $22.9 \%$, respectively), whereas that of $\mathrm{MN}$ was significantly $(P<0.05)$ decreased $($ mean $=-6.7 \%)$ when SBM was replaced with a variety of RUP sources in 34 treatment comparisons. In those 34 comparisons, cows 
consumed on average $18.7 \mathrm{~kg}$ of DM daily. The detrimental effect of replacing degradable protein sources with RUP supplements on the ruminal outflow of MN has been associated with a shortage of energy, AA, peptides, or $\mathrm{NH}_{3} \mathrm{~N}$ in the rumen (Hoover and Stokes, 1991; Clark et al., 1992). However, in some studies in which DMI was as high as in this experiment $(\sim 23 \mathrm{~kg} / \mathrm{d})$, the replacement of SBM with blood meal, fish meal, extruded SBM, or corn gluten meal did not affect the ruminal outflow of NAN, NANMN (Klusmeyer et al., 1991; Reynal et al., 2003), and MN (Reynal et al., 2003).

It is well known that decreases in ruminal retention time associated with increases in DMI can decrease the extent of protein degradation in the rumen (NRC, 1985; Satter, 1986). The magnitude of this effect, however, would be expected to be relatively small even for large increases in DMI (Satter, 1986). Loerch et al. (1983) reported that the in situ disappearance of $\mathrm{N}$ for various sources of supplemental $\mathrm{CP}$ declined as the ruminal $\mathrm{pH}$ approached 6.0 and this effect was more pronounced for SBM than for sources of RUP (e.g., blood meal, corn gluten meal). In this experiment (Table 5), as in those in which DMI averaged about $23 \mathrm{~kg} / \mathrm{d}$ (Klusmeyer et al., 1991; Reynal et al., 2003), the mean ruminal $\mathrm{pH}$ for the SBM-based diets was 6.0 or less. Therefore, it would seem reasonable to suggest that high DMI and relatively low ruminal $\mathrm{pH}$ might have contributed to reduce the ruminal degradability of proteins in SBM to a larger extent than for those in AMB, resulting in more passage of NANMN to the duodenum from these sources of CP. At the same time, high DMI coupled with extensive fermentation of $\mathrm{OM}$ in the rumen of cows fed AMB might have resulted in an adequate supply of nutrients in the rumen, preventing in turn a depression of the synthesis and the efficiency of synthesis of microbial protein. Additionally, the proportion of dietary CP supplied from AMB, which ranged from 9 to $20 \%$, might have been insufficient for improving quantitatively the ruminal escape of NANMN and (or) limiting microbial growth. In part, this suggestion is supported by results from a summary of studies (Ipharraguerre, 2004; Ipharraguerre and Clark, 2005a) indicating that the mean outflow of NANMN from the rumen of dairy cows fed diets that contained RUP supplements was significantly increased when RUP provided more than $25 \%$ of the dietary CP.

The intake of $\mathrm{N}$ increased from 510 to $668 \mathrm{~g} / \mathrm{d}$ as $\mathrm{CP}$ increased in the diet from LCP to HCP (Table 6). The passage to the small intestine of total $\mathrm{N}$ and NAN (expressed as $\mathrm{g} / \mathrm{d}$ and as percentage of $\mathrm{N}$ intake) followed the same trend as $\mathrm{N}$ intake, but differences between MCP and HCP were not significant. For the LCP diets, the ruminal outflow of $\mathrm{N}$ and NAN was on average 7 and $2.9 \%$ greater than $\mathrm{N}$ intake, suggesting that the supply of RDP from this diet might have been slightly marginal. However, the passage of MN to the duodenum and the efficiency of microbial growth were not affected by the percentage of dietary CP. Consequently, it is possible that more endogenous $\mathrm{N}$ was recycled into the rumen of cows fed the LCP diet to sustain microbial growth and fermentation. This observation is supported by studies with steers (Marini and Van Amburgh, 2003) and dairy cows (Al-Dehneh et al., 1997) in which it was estimated that the amount and proportion of endogenous urea $\mathrm{N}$ used by ruminal microbes increased when the availability of $\mathrm{N}$ in the rumen, but not of energy, became increasingly deficient.

The escape of NANMN from the rumen increased as the concentration of CP increased in the diet, but differences between LCP and MCP were not significant. As a result, proportionally less MN and more NANMN contributed to the intestinal supply of NAN as dietary CP increased from LCP to HCP. These results agree with previous research indicating that the ruminal outflow of NAN increased, whereas the passage to duodenum of MN and the efficiency of microbial protein synthesis remained unaffected when the percentage of dietary CP varied from 11.3 to 15.0 (Klusmeyer et al., 1990), from 15.8 to 20.3 (Reynal et al., 2003), or from 13.1 to 23.1 (Stern et al., 1983).

The amount of $\mathrm{N}$ apparently digested in the intestines tended to increase in response to increments in the input of dietary CP (Table 6). This response, however, can be attributed to increases in $\mathrm{N}$ intake because the postruminal digestibility of $\mathrm{N}$ expressed as percentage of $\mathrm{N}$ intake or as percentage of $\mathrm{N}$ passage to duodenum was similar among treatments. Likewise, the amount of $\mathrm{N}$ apparently digested in the total tract reflected changes in $\mathrm{N}$ intake, being lowest for LCP, intermediate for MCP, and highest for HCP. Compared with the LCP diet, feeding the MCP and HCP diets increased the percentage of $\mathrm{N}$ intake apparently digested in the total tract. Because the intestinal digestibility did not differ among treatments, it is likely that this effect corresponded to 1) a dilution of metabolic fecal $\mathrm{N}$ losses and 2) increased protein degradation and losses of $\mathrm{NH}_{3} \mathrm{~N}$ from the rumen of cows fed the MCP and $\mathrm{HCP}$ diets. Additionally, the suggested larger incorporation of endogenous $\mathrm{N}$ into microbial protein synthesized in the rumen of cows fed the LCP diet might have contributed to explain these differences. Similar outcomes have been reported in other experiments in which the intake of $\mathrm{N}$ was enhanced by increasing the percentage of dietary CP (Klusmeyer et al., 1990; Cunningham et al., 1996).

\section{Intake and Ruminal Outflow of AA}

As shown in Table 7, the interaction between the percentage and source of $\mathrm{CP}$ was significant for the 
Table 7. Least square means for intakes of AA ( $\mathrm{g} / \mathrm{d})$ by lactating dairy cows fed diets containing different percentages and sources of CP. ${ }^{1}$

\begin{tabular}{|c|c|c|c|c|c|c|c|c|c|c|}
\hline \multirow[b]{3}{*}{ AA } & \multirow{2}{*}{\multicolumn{2}{|c|}{ LCP }} & \multirow{2}{*}{\multicolumn{2}{|c|}{ MCP }} & \multirow{2}{*}{\multicolumn{2}{|c|}{ HCP }} & \multirow[b]{3}{*}{ SEM } & \multicolumn{3}{|c|}{ Effect $^{2}(P>\mathrm{F})$} \\
\hline & & & & & & & & & & $\mathrm{CP} \% \times$ \\
\hline & SBM & $\mathrm{AMB}$ & SBM & $\mathrm{AMB}$ & SBM & $\mathrm{AMB}$ & & $\mathrm{CP} \%$ & Source & source \\
\hline \multicolumn{11}{|l|}{ Essential } \\
\hline Arg & $166^{\mathrm{c}}$ & $167^{\mathrm{c}}$ & $218^{\mathrm{b}}$ & $224^{\mathrm{b}}$ & $245^{\mathrm{a}}$ & $238^{\mathrm{a}}$ & 7.2 & 0.0001 & $\mathrm{NS}^{3}$ & NS \\
\hline His & $71^{\mathrm{c}}$ & $74^{\mathrm{c}}$ & $91^{\mathrm{b}}$ & $92^{\mathrm{b}}$ & $101^{\mathrm{a}}$ & $104^{\mathrm{a}}$ & 3.2 & 0.0001 & NS & NS \\
\hline Ile & 127 & 125 & 164 & 170 & 181 & 166 & 5.3 & 0.0001 & NS & 0.08 \\
\hline Leu & $269^{\mathrm{c}}$ & $284^{\mathrm{c}}$ & $322^{\mathrm{b}}$ & $324^{\mathrm{b}}$ & $361^{\mathrm{a}}$ & $354^{\mathrm{a}}$ & 11.3 & 0.0001 & NS & NS \\
\hline Lys & 129 & 128 & 177 & 187 & 215 & 199 & 6.0 & 0.0001 & NS & 0.05 \\
\hline Met & $55^{\mathrm{b}}$ & $60^{\mathrm{b}}$ & $54^{\mathrm{b}}$ & $59^{b}$ & $63^{\mathrm{a}}$ & $71^{\mathrm{a}}$ & 2.2 & 0.0001 & 0.001 & NS \\
\hline Phe & $147^{\mathrm{c}}$ & $152^{\mathrm{c}}$ & $186^{\mathrm{b}}$ & $191^{\mathrm{b}}$ & $211^{\mathrm{a}}$ & $202^{\mathrm{a}}$ & 6.3 & 0.0001 & NS & NS \\
\hline Thr & 115 & 117 & 142 & 145 & 169 & 155 & 4.9 & 0.0001 & NS & 0.09 \\
\hline Val & 160 & 171 & 201 & 204 & 193 & 231 & 7.0 & 0.0001 & 0.002 & 0.02 \\
\hline Total & $1240^{\mathrm{c}}$ & $1278^{\mathrm{c}}$ & $1555^{\mathrm{b}}$ & $1597^{b}$ & $1740^{\mathrm{a}}$ & $1721^{\mathrm{a}}$ & 53.3 & 0.0001 & NS & NS \\
\hline \multicolumn{11}{|c|}{ Nonessential } \\
\hline Ala & 183 & 195 & 214 & 283 & 236 & 243 & 7.9 & 0.0001 & 0.0001 & 0.0002 \\
\hline Asp & 298 & 294 & 389 & 402 & 455 & 403 & 12.7 & 0.0001 & NS & 0.02 \\
\hline Glu & 480 & 473 & 616 & 636 & 712 & 621 & 20.0 & 0.0001 & 0.06 & 0.008 \\
\hline Gly & $132^{\mathrm{c}}$ & $146^{\mathrm{c}}$ & $168^{\mathrm{b}}$ & $170^{\mathrm{b}}$ & $190^{\mathrm{a}}$ & $208^{\mathrm{a}}$ & 6.2 & 0.0001 & 0.01 & $\mathrm{NS}$ \\
\hline Pro & $207^{\mathrm{c}}$ & $220^{c}$ & $245^{\mathrm{b}}$ & $246^{\mathrm{b}}$ & $274^{\mathrm{a}}$ & $269^{\mathrm{a}}$ & 8.7 & 0.0001 & NS & NS \\
\hline Ser & 126 & 131 & 157 & 160 & 206 & 179 & 5.6 & 0.0001 & NS & 0.005 \\
\hline Tyr & $79^{c}$ & $80^{c}$ & $88^{\mathrm{b}}$ & $88^{b}$ & $100^{\mathrm{a}}$ & $101^{\mathrm{a}}$ & 3.1 & 0.0001 & NS & NS \\
\hline Total & 1506 & 1540 & 1877 & 1985 & 2173 & 2025 & 64.1 & 0.0001 & NS & 0.07 \\
\hline Total AA & $2746^{\mathrm{c}}$ & $2818^{c}$ & $3432^{\mathrm{b}}$ & $3582^{\mathrm{b}}$ & $3914^{\mathrm{a}}$ & $3746^{\mathrm{a}}$ & 117.4 & 0.0001 & NS & NS \\
\hline
\end{tabular}

${ }^{a, b, c}$ Means within a row with different superscript differ significantly for the main effect of CP percentage. Pairwise comparisons were calculated using the appropriate standard error.

${ }^{1} \mathrm{AMB}=$ Animal-marine protein blend, $\mathrm{HCP}=$ high $\mathrm{CP}$ diet, $\mathrm{LCP}=$ low $\mathrm{CP}$ diet, $\mathrm{MCP}=$ medium $\mathrm{CP}$ diet, $\mathrm{SBM}=$ soybean meal.

${ }^{2} \mathrm{CP} \%=$ Percentage of $\mathrm{CP}$, Source $=$ source of $\mathrm{CP}, \mathrm{CP} \% \times$ source $=$ interaction between percentage and source of CP.

${ }^{3}$ Nonsignificant $(P>0.10)$.

intake of Ile $(P<0.08)$, Lys, Thr $(P<0.09)$, Val, Ala, Asp, Glu, Ser, and total nonessential AA (NEAA). With the exception of Val and Ala, the HCP/SBM diet resulted in higher intakes of those AA than the $\mathrm{HCP} /$ AMB diet, but differences between sources of $\mathrm{CP}$ at lower concentrations of dietary $\mathrm{CP}$ were not significant. In contrast, the intakes of $\mathrm{Val}$ and $\mathrm{Ala}$ were higher for AMB than for SBM for HCP and MCP diets, respectively. Across percentages of $\mathrm{CP}$, replacing a portion of SBM with AMB increased the intake of Met (mean = $6 \mathrm{~g} / \mathrm{d})$, Val $($ mean $=17 \mathrm{~g} / \mathrm{d})$, and Ala $($ mean $=29 \mathrm{~g} / \mathrm{d})$, but decreased that of Glu (mean $=-26 \mathrm{~g} / \mathrm{d}$ ). Across sources of $\mathrm{CP}$, increasing the $\mathrm{CP}$ of the diet increased the intake of all individual AA, EAA, NEAA, and total AA, but differences between LCP and MCP were not significant for the intake of Met. Because the source of supplemental CP and corn grain were the only ingredients that varied in the diets, these findings can be attributed to variations in DMI (Table 3) and differences in the AA composition of SBM, AMB (Table 2), and corn grain.

The partial replacement of SBM with AMB in the diet did not affect the intestinal supply of total EAA, total NEAA, and total AA of NANMN origin (Table 8). However, feeding AMB increased the amount of His and Pro $(P<0.07)$ that passed to the duodenum in the NANMN fraction. The ruminal outflow of individual AA, total EAA, total NEAA, and total AA of microbial origin (Table 9) and NAN origin (Table 10) were unaffected by the source of CP. In a summary of 41 treatment comparisons (Ipharraguerre, 2004) it was shown that increasing the RUP content of the diet of dairy cows that consumed on average $19.5 \mathrm{~kg} / \mathrm{d}$ of DM enhanced the amount of Lys, Met, EAA, and total AA that reached the small intestine. The magnitude and significance of these responses, however, usually depended on the RUP supplement and the source of CP in the control diet. For instance, when mean responses were computed using only 25 comparisons in which SBM was the CP supplement in the control diet (Ipharraguerre and Clark, 2005a), the improvement in the ruminal outflow of Lys and Met caused by the feeding of RUP supplements in the experimental diet was small (3.4 and 2.5\%, respectively) and not significant $(P>$ 0.05). Rulquin and Vérité (1993) indicated that most of the variation in the profile of EAA that exit the rumen is accounted for by the individual EAA content of the RUP and the proportion of RUP that is consumed and delivered to the lower gastrointestinal tract. Even though the percentage of many EAA was higher in AMB 
Table 8. Least square means for passage of nonammonia nonmicrobial AA ( $\mathrm{g} / \mathrm{d}$ ) to the duodenum of lactating dairy cows fed diets containing different percentages and sources of CP. ${ }^{1}$

\begin{tabular}{|c|c|c|c|c|c|c|c|c|c|c|}
\hline \multirow[b]{3}{*}{$\mathrm{AA}$} & \multirow{2}{*}{\multicolumn{2}{|c|}{ LCP }} & \multirow{2}{*}{\multicolumn{2}{|c|}{$\mathrm{MCP}$}} & \multirow{2}{*}{\multicolumn{2}{|c|}{$\mathrm{HCP}$}} & \multirow[b]{3}{*}{ SEM } & \multicolumn{3}{|c|}{$\operatorname{Effect}^{2}(P>\mathrm{F})$} \\
\hline & & & & & & & & & & $\mathrm{CP} \% \times$ \\
\hline & SBM & $\mathrm{AMB}$ & $\mathrm{SBM}$ & $\mathrm{AMB}$ & SBM & $\mathrm{AMB}$ & & $\mathrm{CP} \%$ & Source & source \\
\hline \multicolumn{11}{|l|}{ Essential } \\
\hline Arg & $60^{\mathrm{b}}$ & $71^{\mathrm{b}}$ & $73^{\mathrm{b}}$ & $71^{\mathrm{b}}$ & $85^{\mathrm{a}}$ & $110^{\mathrm{a}}$ & 12.5 & 0.02 & $\mathrm{NS}^{3}$ & NS \\
\hline His & $33^{\mathrm{b}}$ & $41^{\mathrm{b}}$ & $39^{b}$ & $44^{\mathrm{b}}$ & $45^{\mathrm{a}}$ & $63^{\mathrm{a}}$ & 5.7 & 0.01 & 0.03 & NS \\
\hline Ile & $53^{\mathrm{b}}$ & $57^{\mathrm{b}}$ & $65^{\mathrm{b}}$ & $56^{\mathrm{b}}$ & $78^{\mathrm{a}}$ & $90^{\mathrm{a}}$ & 12.9 & 0.05 & NS & NS \\
\hline Leu & $139^{b}$ & $161^{\mathrm{b}}$ & $160^{\mathrm{b}}$ & $164^{\mathrm{b}}$ & $178^{\mathrm{a}}$ & $234^{\mathrm{a}}$ & 24.9 & 0.05 & NS & NS \\
\hline Lys & $65^{\mathrm{b}}$ & $71^{b}$ & $79^{\mathrm{b}}$ & $77^{\mathrm{b}}$ & $124^{\mathrm{a}}$ & $122^{\mathrm{a}}$ & 22.6 & 0.03 & NS & $\mathrm{NS}$ \\
\hline Met & $36^{\mathrm{b}}$ & $32^{\mathrm{b}}$ & $30^{\mathrm{b}}$ & $32^{\mathrm{b}}$ & $44^{\mathrm{a}}$ & $50^{\mathrm{a}}$ & 7.5 & 0.07 & NS & NS \\
\hline Phe & $61^{\mathrm{b}}$ & $75^{\mathrm{b}}$ & $76^{\mathrm{b}}$ & $75^{\mathrm{b}}$ & $87^{\mathrm{a}}$ & $115^{\mathrm{a}}$ & 13.3 & 0.03 & NS & NS \\
\hline Thr & $60^{\mathrm{b}}$ & $66^{\mathrm{b}}$ & $72^{\mathrm{b}}$ & $69^{\mathrm{b}}$ & $87^{\mathrm{a}}$ & $97^{\mathrm{a}}$ & 14.2 & 0.07 & NS & NS \\
\hline Val & $63^{b}$ & $76^{\mathrm{b}}$ & $78^{\mathrm{b}}$ & $81^{b}$ & $91^{\mathrm{a}}$ & $127^{\mathrm{a}}$ & 15.4 & 0.03 & NS & NS \\
\hline Total & $571^{\mathrm{b}}$ & $653^{\mathrm{b}}$ & $641^{\mathrm{b}}$ & $673^{\mathrm{b}}$ & $819^{a}$ & $1012^{\mathrm{a}}$ & 121.5 & 0.02 & NS & NS \\
\hline \multicolumn{11}{|c|}{ Nonessential } \\
\hline Ala & $71^{\mathrm{b}}$ & $77^{\mathrm{b}}$ & $85^{\mathrm{b}}$ & $81^{b}$ & $101^{\mathrm{a}}$ & $139^{\mathrm{a}}$ & 19.8 & 0.05 & NS & NS \\
\hline Asp & $98^{\mathrm{b}}$ & $102^{\mathrm{b}}$ & $120^{\mathrm{b}}$ & $110^{\mathrm{b}}$ & $152^{\mathrm{a}}$ & $175^{\mathrm{a}}$ & 28.2 & 0.05 & NS & NS \\
\hline Glu & $190^{\mathrm{b}}$ & $205^{\mathrm{b}}$ & $224^{b}$ & $207^{b}$ & $259^{\mathrm{a}}$ & $314^{\mathrm{a}}$ & 38.3 & 0.04 & NS & NS \\
\hline Gly & $65^{\mathrm{b}}$ & $81^{b}$ & $86^{\mathrm{b}}$ & $76^{\mathrm{b}}$ & $100^{\mathrm{a}}$ & $132^{\mathrm{a}}$ & 18.4 & 0.04 & NS & NS \\
\hline Pro & $84^{\mathrm{b}}$ & $98^{\mathrm{b}}$ & $97^{\mathrm{b}}$ & $103^{b}$ & $107^{\mathrm{a}}$ & $148^{\mathrm{a}}$ & 14.3 & 0.03 & 0.07 & NS \\
\hline Ser & $65^{\mathrm{b}}$ & $74^{\mathrm{b}}$ & $75^{\mathrm{b}}$ & $79^{b}$ & $87^{\mathrm{a}}$ & $112^{\mathrm{a}}$ & 14.0 & 0.07 & NS & NS \\
\hline Tyr & $22^{\mathrm{b}}$ & $18^{b}$ & $27^{\mathrm{b}}$ & $21^{\mathrm{b}}$ & $35^{\mathrm{a}}$ & $50^{\mathrm{a}}$ & 10.0 & 0.04 & NS & NS \\
\hline Total & $596^{\mathrm{b}}$ & $655^{\mathrm{b}}$ & $714^{\mathrm{b}}$ & $676^{\mathrm{b}}$ & $841^{\mathrm{a}}$ & $1069^{a}$ & 139.1 & 0.04 & NS & NS \\
\hline Total AA & $1167^{\mathrm{b}}$ & $1311^{b}$ & $1323^{\mathrm{b}}$ & $1352^{\mathrm{b}}$ & $1662^{\mathrm{a}}$ & $2082^{\mathrm{a}}$ & 261.8 & 0.004 & NS & NS \\
\hline
\end{tabular}

${ }^{a, b}$ Means within a row with different superscript differ significantly for the main effect of CP percentage. Pairwise comparisons were calculated using the appropriate standard error.

${ }^{1} \mathrm{AMB}=$ Animal-marine protein blend, $\mathrm{HCP}=$ high $\mathrm{CP}$ diet, $\mathrm{LCP}=$ low $\mathrm{CP}$ diet, $\mathrm{MCP}=$ medium $\mathrm{CP}$ diet, $\mathrm{SBM}=$ soybean meal.

${ }^{2} \mathrm{CP} \%=$ Percentage of $\mathrm{CP}$, Source $=$ source of $\mathrm{CP}, \mathrm{CP} \% \times$ source $=$ interaction between percentage and source of CP.

${ }^{3}$ Nonsignificant $(P>0.10)$.

than in SBM (Table 2), the CP supplement supplied only 9 to $20 \%$ of total $\mathrm{N}$ intake and NANMN contributed on average only $50 \%$ of the NAN that passed to the duodenum when diets that contained SBM and AMB were fed (Table 6). Therefore, it appears that the small proportion of feed $\mathrm{CP}$ reaching the small intestine and the lack of significant differences in degradability obtained between SBM- and AMB-containing diets probably prevented finding significant differences between these sources of CP for their ability to supply AA to the small intestine. As previously suggested, the large amount of feed consumed by the cows combined with a ruminal $\mathrm{pH}$ of about 6 and relatively small proportions but recommended amounts of dietary CP supplied from AMB might have contributed to equalize the ruminal escape of protein from these diets that contained SBM and AMB.

Increasing $\mathrm{CP}$ in the diet enhanced or tended to enhance the passage to the duodenum of all $\mathrm{AA}$ of NANMN origin; however, differences were not significant between LCP and MCP (Table 8). Because the ruminal outflow of microbial AA was not affected by the percentage of dietary CP (Table 9), the amount of all AA that reached the small intestine in the NAN fraction, except for Met, also increased or tended to increase only when the HCP diets were fed (Table 10). Apparently, changes in the intestinal supply of AA in response to additional dietary $\mathrm{CP}$ paralleled the described differences in AA intake. These results agree with data reviewed in other reports (Clark et al., 1992; Ipharraguerre, 2004), which indicate that a positive and high correlation exists between $\mathrm{N}$ intake and flow of NAN, NANMN, and total AA to the duodenum.

Research suggests that Lys and Met are the 2 EAA that most frequently limit the performance of dairy cows fed a broad variety of diets (Sloan, 1997; NRC, 2001). To maximize milk protein output, it has been suggested that Lys and Met must provide about 7.0 and $2.5 \%$, respectively, of the total $\mathrm{AA}$ that pass to the small intestine of cows fed corn-based diets (NRC, 2001). Neither the percentage nor the source of CP significantly altered the proportion of Lys (Figure 1) and Met (Figure 2) in the intestinal supply of AA. In relation to numerical trends, when CP increased in the diet, the percentage of Lys in total AA reaching the duodenum increased, whereas that of Met decreased, probably denoting a decline in the relative contribution of corn protein to the ruminal outflow of NANMN. This trend was less evident when AMB replaced a portion of SBM in the diet. Because the passage to duodenum 
Table 9. Least square means for passage of microbial AA $(\mathrm{g} / \mathrm{d})$ to the duodenum of lactating dairy cows fed diets containing different percentages and sources of CP. ${ }^{1}$

\begin{tabular}{|c|c|c|c|c|c|c|c|c|c|c|}
\hline \multirow[b]{3}{*}{$\mathrm{AA}$} & \multirow{2}{*}{\multicolumn{2}{|c|}{ LCP }} & \multirow{2}{*}{\multicolumn{2}{|c|}{ MCP }} & \multirow{2}{*}{\multicolumn{2}{|c|}{$\mathrm{HCP}$}} & \multirow[b]{3}{*}{ SEM } & \multicolumn{3}{|c|}{ Effect $^{2}(P>\mathrm{F})$} \\
\hline & & & & & & & & & & $\mathrm{CP} \% \times$ \\
\hline & SBM & $\mathrm{AMB}$ & SBM & $\mathrm{AMB}$ & SBM & $\mathrm{AMB}$ & & $\mathrm{CP} \%$ & Source & source \\
\hline \multicolumn{11}{|l|}{ Essential } \\
\hline Arg & 58 & 67 & 65 & 62 & 69 & 61 & 6.2 & $\mathrm{NS}^{3}$ & NS & NS \\
\hline $\mathrm{His}$ & 22 & 25 & 24 & 24 & 26 & 24 & 2.3 & NS & NS & NS \\
\hline Ile & 67 & 77 & 76 & 74 & 78 & 72 & 6.8 & NS & NS & NS \\
\hline Leu & 101 & 115 & 113 & 110 & 120 & 107 & 10.0 & NS & NS & NS \\
\hline Lys & 85 & 99 & 99 & 96 & 103 & 96 & 9.8 & NS & NS & NS \\
\hline Met & 27 & 28 & 29 & 29 & 25 & 22 & 3.4 & NS & NS & NS \\
\hline Phe & 66 & 72 & 71 & 70 & 75 & 68 & 6.5 & NS & NS & NS \\
\hline Thr & 66 & 79 & 74 & 72 & 75 & 76 & 7.8 & NS & NS & NS \\
\hline Val & 77 & 88 & 85 & 84 & 88 & 81 & 7.7 & NS & NS & NS \\
\hline Total & 568 & 651 & 637 & 620 & 659 & 607 & 58.2 & NS & NS & NS \\
\hline \multicolumn{11}{|c|}{ Nonessential } \\
\hline Ala & 108 & 125 & 120 & 120 & 121 & 113 & 10.4 & NS & NS & NS \\
\hline Asp & 161 & 191 & 187 & 180 & 189 & 185 & 17.8 & NS & NS & NS \\
\hline Glu & 178 & 207 & 200 & 193 & 208 & 186 & 17.9 & NS & NS & NS \\
\hline Gly & 82 & 95 & 92 & 91 & 92 & 87 & 7.9 & NS & NS & NS \\
\hline Pro & 49 & 56 & 54 & 51 & 58 & 49 & 4.6 & NS & NS & NS \\
\hline Ser & 67 & 86 & 78 & 77 & 82 & 83 & 7.9 & NS & NS & NS \\
\hline Tyr & 64 & 73 & 71 & 69 & 73 & 72 & 6.3 & NS & NS & NS \\
\hline Total & 710 & 834 & 801 & 781 & 823 & 770 & 71.1 & NS & NS & NS \\
\hline Total AA & 1278 & 1485 & 1438 & 1401 & 1482 & 1377 & 128.9 & NS & NS & NS \\
\hline
\end{tabular}

${ }^{1} \mathrm{AMB}=$ Animal-marine protein blend, $\mathrm{HCP}=$ high $\mathrm{CP}$ diet, $\mathrm{LCP}=$ low $\mathrm{CP}$ diet, $\mathrm{MCP}=$ medium $\mathrm{CP}$ diet, $\mathrm{SBM}=$ soybean meal.

${ }^{2} \mathrm{CP} \%=$ Percentage of $\mathrm{CP}$, Source $=$ source of $\mathrm{CP}, \mathrm{CP} \% \times$ source $=$ interaction between percentage and source of $\mathrm{CP}$.

${ }^{3}$ Nonsignificant $(P>0.10)$.

of MN and NANMN were not affected by the source of supplemental $\mathrm{CP}$, it is likely that the profile of EAA in AMB, which was balanced to supply adequate amounts of limiting AA for milk protein synthesis (Beede et al., 1994), ameliorated fluctuations in the composition of total AA reaching the small intestine. The HCP/SBM and MCP/AMB diets resulted in percentages of Lys and Met in duodenal digesta that most closely approached the aforementioned targets. However, none of the diets resulted in an ideal profile of Lys and Met in total AA delivered to the duodenum. Based on estimations by the NRC (2001), it is recommended that, under practical situations, the contents of Lys and Met in MP should be 6.6 and $2.2 \%$, respectively, to achieve maximum milk protein production (Schwab et al., 2003). Because the proportion of individual ingredients in the AMB product has not been disclosed, it is not possible to estimate the proportion of EAA in MP that was supplied to the cows by the experimental diets.

\section{Production of Milk and Milk Composition}

Yields of milk and 3.5\% FCM were not affected significantly by treatments (Table 11). Likewise, neither the percentage nor the source of CP altered significantly mean milk production during the first $210 \mathrm{~d}$ of lactation (range $=36.3$ to $39.4 \mathrm{~kg} / \mathrm{d}$ ) in the companion study (Ipharraguerre and Clark, 2005b). In a number of experiments, it was observed that decreasing the $\mathrm{CP}$ content of the diet of high-producing cows from 18 and 19 to 16 and $17 \%$ did not depress DMI or milk production (Cunningham et al., 1996; Wu and Satter, 2000; Broderick, 2003). However, reducing dietary CP to within a range of 13 to $15 \%$ depressed the intake of $\mathrm{DM}$ and the output of milk (Wu and Satter, 2000; Frank and Swensson, 2002; Broderick, 2003). Collectively, these results support the view that lower inputs of dietary $\mathrm{CP}$ exert negative effects on milk production partly by decreasing DMI (Wohlt et al., 1978; Clark and Davis, 1980; Oldham, 1984), which did not occur in this experiment. Additionally, the amount of milk produced by cows in this study (mean $=30.1 \mathrm{~kg} / \mathrm{d}$ ) appeared to be insufficient for detecting improvements in milk yield in response to increased supply of AA to the duodenum. Data from several experiments showed that the replacement of SBM with RUP supplements of marine, animal, and (or) plant origin generally failed to improve significantly milk yield in dairy cows that produced on average up to about $30 \mathrm{~kg} / \mathrm{d}$ (Santos et al., 1998; Ipharraguerre and Clark, 2005a).

The percentage and yield of fat, $\mathrm{CP}$, true protein, and total solids in milk were not significantly altered by the 
Table 10. Least square means for passage of total AA $(\mathrm{g} / \mathrm{d})$ to the duodenum of lactating dairy cows fed diets containing different percentages and sources of CP. ${ }^{1}$

\begin{tabular}{|c|c|c|c|c|c|c|c|c|c|c|}
\hline \multirow[b]{3}{*}{$\mathrm{AA}$} & \multirow{2}{*}{\multicolumn{2}{|c|}{ LCP }} & \multirow{2}{*}{\multicolumn{2}{|c|}{$\mathrm{MCP}$}} & \multirow{2}{*}{\multicolumn{2}{|c|}{$\mathrm{HCP}$}} & \multirow[b]{3}{*}{ SEM } & \multicolumn{3}{|c|}{ Effect $^{2}(P>\mathrm{F})$} \\
\hline & & & & & & & & & & $\mathrm{CP} \% \times$ \\
\hline & SBM & $\mathrm{AMB}$ & SBM & AMB & SBM & $\mathrm{AMB}$ & & $\mathrm{CP} \%$ & Source & source \\
\hline \multicolumn{11}{|l|}{ Essential } \\
\hline Arg & $118^{\mathrm{b}}$ & $129^{b}$ & $136^{\mathrm{b}}$ & $128^{\mathrm{b}}$ & $155^{\mathrm{a}}$ & $166^{\mathrm{a}}$ & 15.2 & 0.02 & $\mathrm{NS}^{3}$ & NS \\
\hline His & $55^{\mathrm{b}}$ & $60^{\mathrm{b}}$ & $63^{\mathrm{b}}$ & $64^{\mathrm{b}}$ & $71^{\mathrm{a}}$ & $84^{\mathrm{a}}$ & 6.8 & 0.008 & NS & NS \\
\hline Ile & $120^{\mathrm{b}}$ & $127^{\mathrm{b}}$ & $141^{\mathrm{b}}$ & $124^{\mathrm{b}}$ & $157^{\mathrm{a}}$ & $157^{\mathrm{a}}$ & 14.6 & 0.03 & NS & $\mathrm{NS}$ \\
\hline Leu & $240^{\mathrm{b}}$ & $251^{\mathrm{b}}$ & $272^{\mathrm{b}}$ & $258^{\mathrm{b}}$ & $299^{\mathrm{a}}$ & $338^{\mathrm{a}}$ & 29.0 & 0.02 & NS & NS \\
\hline Lys & $150^{\mathrm{b}}$ & $163^{\mathrm{b}}$ & $178^{\mathrm{b}}$ & $164^{\mathrm{b}}$ & $228^{\mathrm{a}}$ & $212^{\mathrm{a}}$ & 26.4 & 0.02 & NS & NS \\
\hline Met & 63 & 58 & 60 & 58 & 69 & 67 & 8.0 & NS & NS & NS \\
\hline Phe & $127^{b}$ & $135^{\mathrm{b}}$ & $146^{\mathrm{b}}$ & $137^{\mathrm{b}}$ & $163^{\mathrm{a}}$ & $179^{\mathrm{a}}$ & 15.2 & 0.01 & NS & NS \\
\hline Thr & $126^{\mathrm{b}}$ & $137^{\mathrm{b}}$ & $147^{\mathrm{b}}$ & $133^{\mathrm{b}}$ & $163^{\mathrm{a}}$ & $169^{a}$ & 15.6 & 0.04 & NS & NS \\
\hline Val & $140^{\mathrm{b}}$ & $153^{b}$ & $163^{\mathrm{b}}$ & $156^{\mathrm{b}}$ & $180^{\mathrm{a}}$ & $203^{\mathrm{a}}$ & 15.0 & 0.02 & NS & NS \\
\hline Total & $1140^{\mathrm{b}}$ & $1213^{\mathrm{b}}$ & $1280^{\mathrm{b}}$ & $1225^{\mathrm{b}}$ & $1488^{\mathrm{a}}$ & $1573^{\mathrm{a}}$ & 143.3 & 0.02 & NS & NS \\
\hline \multicolumn{11}{|c|}{ Nonessential } \\
\hline Ala & $180^{b}$ & $190^{\mathrm{b}}$ & $205^{\mathrm{b}}$ & $191^{\mathrm{b}}$ & $223^{\mathrm{a}}$ & $248^{\mathrm{a}}$ & 18.7 & 0.03 & NS & NS \\
\hline Asp & $259^{\mathrm{b}}$ & $278^{\mathrm{b}}$ & $307^{b}$ & $274^{\mathrm{b}}$ & $343^{a}$ & $354^{\mathrm{a}}$ & 32.2 & 0.02 & NS & NS \\
\hline Glu & $368^{b}$ & $379^{b}$ & $423^{\mathrm{b}}$ & $379^{\mathrm{b}}$ & $469^{\mathrm{a}}$ & $493^{\mathrm{a}}$ & 44.1 & 0.03 & NS & NS \\
\hline Gly & $148^{\mathrm{b}}$ & $173^{\mathrm{b}}$ & $178^{\mathrm{b}}$ & $165^{\mathrm{b}}$ & $193^{\mathrm{a}}$ & $210^{\mathrm{a}}$ & 20.9 & 0.06 & NS & NS \\
\hline Pro & $133^{\mathrm{b}}$ & $140^{\mathrm{b}}$ & $150^{\mathrm{b}}$ & $145^{\mathrm{b}}$ & $166^{\mathrm{a}}$ & $191^{\mathrm{a}}$ & 16.0 & 0.01 & NS & NS \\
\hline Ser & $133^{\mathrm{b}}$ & $142^{\mathrm{b}}$ & $153^{\mathrm{b}}$ & $147^{\mathrm{b}}$ & $171^{\mathrm{a}}$ & $193^{\mathrm{a}}$ & 16.3 & 0.01 & NS & NS \\
\hline Tyr & $85^{\mathrm{b}}$ & $89^{b}$ & $99^{b}$ & $87^{\mathrm{b}}$ & $108^{\mathrm{a}}$ & $112^{\mathrm{a}}$ & 10.6 & 0.04 & NS & NS \\
\hline Total & $1305^{\mathrm{b}}$ & $1391^{\mathrm{b}}$ & $1515^{\mathrm{b}}$ & $1389^{b}$ & $1676^{\mathrm{a}}$ & $1801^{\mathrm{a}}$ & 160.0 & 0.03 & NS & NS \\
\hline Total AA & $2445^{\mathrm{b}}$ & $2605^{b}$ & $2761^{b}$ & $2615^{\mathrm{b}}$ & $3163^{\mathrm{a}}$ & $3367^{\mathrm{a}}$ & 305.9 & 0.02 & NS & NS \\
\hline
\end{tabular}

${ }^{\mathrm{a}, \mathrm{b}}$ Means within a row with different superscript differ significantly for the main effect of CP percentage. Pairwise comparisons were calculated using the appropriate standard error.

${ }^{1} \mathrm{AMB}=$ Animal-marine protein blend, $\mathrm{HCP}=$ high $\mathrm{CP}$ diet, $\mathrm{LCP}=$ low $\mathrm{CP}$ diet, $\mathrm{MCP}=$ medium $\mathrm{CP}$ diet, $\mathrm{SBM}=$ soybean meal.

${ }^{2} \mathrm{CP} \%=$ Percentage of $\mathrm{CP}$, Source $=$ source of $\mathrm{CP}, \mathrm{CP} \% \times$ source $=$ interaction between percentage and source of CP.

${ }^{3}$ Nonsignificant $(P>0.10)$.

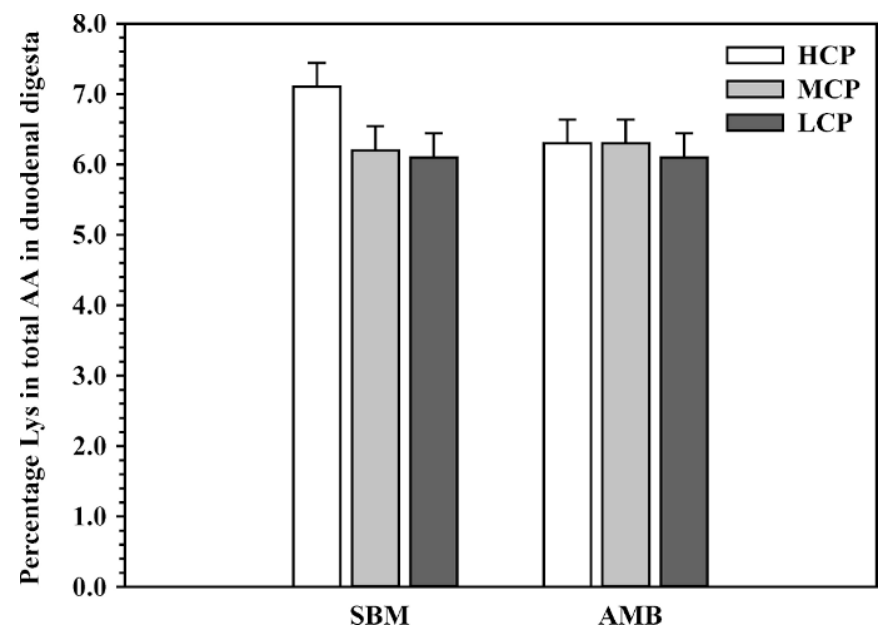

Figure 1. Least square means for the proportion of Lys in total $\mathrm{AA}$ in duodenal digesta of dairy cows fed diets containing high, medium, and low percentages (HCP, MCP, LCP, respectively) and 2 sources [soybean meal (SBM) or animal-marine blend (AMB)] of CP. The effects of the interaction $(P<0.43)$, percentage $(P<0.21)$, and source of $\mathrm{CP}(P<0.37)$ were not significant $(\mathrm{SEM}=0.34)$.

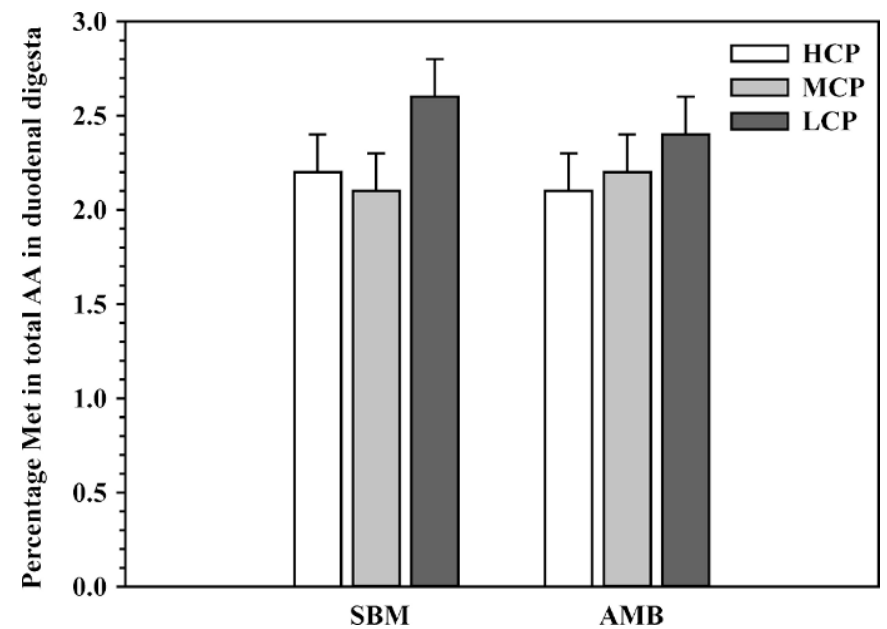

Figure 2. Least square means for the proportion of Met in total $\mathrm{AA}$ in duodenal digesta of dairy cows fed diets containing high, medium, and low percentages (HCP, MCP, LCP, respectively) and 2 sources [soybean meal (SBM) or animal-marine blend (AMB)] of CP. The effects of the interaction $(P<0.77)$, percentage $(P<0.15)$, and source of $\mathrm{CP}(P<0.58)$ were not significant $(\mathrm{SEM}=0.20)$. 
Table 11. Least square means for production and composition of milk from lactating dairy cows fed diets containing different percentages and sources of $\mathrm{CP} .^{1}$

\begin{tabular}{|c|c|c|c|c|c|c|c|c|c|c|}
\hline \multirow[b]{3}{*}{ Item } & \multirow{2}{*}{\multicolumn{2}{|c|}{ LCP }} & \multirow{2}{*}{\multicolumn{2}{|c|}{ MCP }} & \multirow{2}{*}{\multicolumn{2}{|c|}{$\mathrm{HCP}$}} & \multirow[b]{3}{*}{ SEM } & \multicolumn{3}{|c|}{ Effect $^{2}(P>\mathrm{F})$} \\
\hline & & & & & & & & \multirow[b]{2}{*}{$\mathrm{CP} \%$} & \multirow[b]{2}{*}{ Source } & \multirow{2}{*}{$\begin{array}{l}\mathrm{CP} \% \times \\
\text { source }\end{array}$} \\
\hline & SBM & $\mathrm{AMB}$ & SBM & $\mathrm{AMB}$ & SBM & $\mathrm{AMB}$ & & & & \\
\hline Milk, kg/d & 28.6 & 30.5 & 31.0 & 30.3 & 30.2 & 30.1 & 0.8 & $\mathrm{NS}^{3}$ & NS & NS \\
\hline $3.5 \% \mathrm{FCM},{ }^{4} \mathrm{~kg} / \mathrm{d}$ & 27.2 & 29.5 & 29.7 & 29.2 & 29.6 & 28.9 & 0.9 & NS & NS & NS \\
\hline \multicolumn{11}{|l|}{ Fat } \\
\hline$\%$ & 3.21 & 3.31 & 3.24 & 3.30 & 3.43 & 3.27 & 0.17 & NS & NS & NS \\
\hline $\mathrm{kg} / \mathrm{d}$ & 0.91 & 1.01 & 1.00 & 0.99 & 1.02 & 0.98 & 0.05 & NS & NS & NS \\
\hline \multicolumn{11}{|l|}{$\mathrm{CP}$} \\
\hline$\%$ & 3.18 & 3.27 & 3.21 & 3.23 & 3.26 & 3.18 & 0.10 & NS & NS & 0.10 \\
\hline $\mathrm{kg} / \mathrm{d}$ & 0.91 & 0.99 & 0.99 & 0.97 & 0.98 & 0.96 & 0.04 & NS & NS & NS \\
\hline \multicolumn{11}{|l|}{ True protein } \\
\hline$\%$ & 2.97 & 3.07 & 3.00 & 3.02 & 3.06 & 2.98 & 0.10 & NS & NS & 0.09 \\
\hline $\mathrm{kg} / \mathrm{d}$ & 0.86 & 0.91 & 0.91 & 0.92 & 0.90 & 0.88 & 0.04 & NS & NS & NS \\
\hline \multicolumn{11}{|l|}{ Total solids } \\
\hline$\%$ & 12.05 & 12.18 & 12.05 & 12.14 & 12.17 & 12.08 & 0.29 & NS & NS & NS \\
\hline $\mathrm{kg} / \mathrm{d}$ & 3.46 & 3.70 & 3.73 & 3.66 & 3.65 & 3.63 & 0.12 & NS & NS & NS \\
\hline MUN, mg/dL & 9.53 & 7.98 & 11.52 & 11.17 & 13.51 & 14.25 & 0.93 & 0.0001 & NS & 0.05 \\
\hline
\end{tabular}

\footnotetext{
${ }^{1} \mathrm{AMB}=$ Animal-marine protein blend, $\mathrm{HCP}=$ high $\mathrm{CP}$ diet, $\mathrm{LCP}=$ low $\mathrm{CP}$ diet, $\mathrm{MCP}=$ medium $\mathrm{CP}$ diet, $\mathrm{SBM}=$ soybean meal.

${ }^{2} \mathrm{CP} \%=$ Percentage of $\mathrm{CP}$, Source $=$ source of $\mathrm{CP}, \mathrm{CP} \% \times$ source $=$ interaction between percentage and source of CP.

${ }^{3}$ Nonsignificant $(P>0.10)$.

${ }^{4} 3.5 \% \mathrm{FCM}=0.4324(\mathrm{~kg}$ of milk $)+16.216(\mathrm{~kg}$ of fat $)$.
}

percentage and source of dietary CP (Table 11). At LCP in the diet, cows fed AMB tended to produce milk with a higher concentration of $\mathrm{CP}$ and true protein than those fed SBM. These trends were possibly caused by the slightly higher intake of nutrients by cows fed the LCP/AMB diet compared with those fed the LCP/SBM diet. In the companion study (Ipharraguerre and Clark, 2005b), the percentage and source of dietary CP did not influence milk composition; however, the yields of $\mathrm{CP}$ and true protein increased when dietary CP increased from LCP to HCP. In the literature, changes in the concentration and production of milk components in response to higher inputs of dietary $\mathrm{CP}$ within the range used in this experiment have been variable and, frequently, more strongly related to other dietary factors (NRC, 2001; Ipharraguerre, 2004). For instance, Cunningham et al. (1996) reported that increasing dietary CP from 16.4 to $18.4 \%$ did not affect the percentage and yield of protein and fat in milk. However, Broderick (2003) observed that increasing the dietary CP from 15.1 to $18.4 \%$ increased the percentage and yield of milk protein but did not affect the concentration of fat in milk. In contrast, Frank and Swensson (2002) found that increasing the amount of dietary CP from 13.5 to $17.0 \%$ decreased the percentage of protein in milk but did not influence the production of protein or the percentage and yield of fat. In relation to the source of CP, Santos and coworkers (1999) found that replacing SBM with the AMB product to supply 5\% of the dietary DM increased the output of protein without affecting the concentration of protein and fat in milk from dairy cows that produced on average $37.2 \mathrm{~kg} / \mathrm{d}$ of milk. When mean milk production was about $32 \mathrm{~kg} / \mathrm{d}$ per cow, however, the replacement of SBM with RUP supplements significantly decreased milk CP percentage but did not affect the yield of milk $\mathrm{CP}$ or the percentage and yield of milk fat (Ipharraguerre and Clark, 2005a).

When the LCP/AMB diet was fed, the secretion of urea in milk (i.e., MUN) decreased compared with the LCP/SBM diet, but differences among sources of CP were not significant at higher percentages of dietary CP (Table 11). Moreover, mean MUN increased from 8.8 to $13.8 \mathrm{mg} / \mathrm{dL}$ as the amount of CP increased in the diet from LCP to HCP. This response is consistent with increases in the concentration of $\mathrm{NH}_{3} \mathrm{~N}$ in ruminal fluid of cows fed incremental amounts of dietary $\mathrm{CP}$, suggesting that the amount of $\mathrm{NH}_{3} \mathrm{~N}$ absorbed from the rumen into the blood, converted to urea in the liver, and released back into blood increased as additional supplemental CP replaced corn in the diets. Increasing the $\mathrm{CP}$ content of the diet of dairy cows has consistently increased the concentration of MUN (Frank and Swensson, 2002; Leonardi et al., 2003; Broderick, 2003; Ipharraguerre and Clark, 2005b).

\section{CONCLUSIONS}

In this experiment, the percentage of dietary $\mathrm{CP}$, but not the source of supplemental CP, profoundly influenced the intake, ruminal fermentation, intestinal sup- 
ply, and digestion of $\mathrm{N}$ and starch. Increasing the $\mathrm{CP}$ content of the diet from about 14 to $18 \%$ increased the intake, apparent ruminal degradation, and intestinal supply of AA. In contrast, the intake, ruminal fermentation, and total tract digestion of starch decreased as CP increased in the diet. The proportion of starch consumed by the cows that was apparently digested in the small intestine increased in response to higher inputs of dietary CP. Replacing a portion of SBM with AMB increased the intake of Met and $\mathrm{Val}$ and decreased the concentration of $\mathrm{NH}_{3} \mathrm{~N}$ in the rumen, but did not affect the intake of other EAA or the intestinal supply of any EAA and starch. Neither the percentage nor the source of CP improved the proportion of Lys and Met in total $\mathrm{AA}$ that reached the absorption sites in the small intestine.

These results underscore the central role that the interaction between protein and carbohydrate in various segments of the digestive tract plays in modulating the responses to changes in the input of dietary CP. In this context, it appears that the intake of $\mathrm{N}$ by highproducing dairy cows that consume sufficient energy and other nutrients to meet their requirements can be decreased to about 600 to 650 g daily without compromising the supply of MP if the source and amount of dietary $\mathrm{CP}$ and carbohydrate are properly matched. Data also suggest that the supply of RUP to the small intestines of dairy cows that consume large quantities of corn-SBM-based diets might be underestimated by current feeding standards.

\section{ACKNOWLEDGMENTS}

The authors thank H. J. Baker \& Bros., Inc. (Westport, CT) for providing ProLak and partial financial support to complete the research presented in this report.

\section{REFERENCES}

Abramson, S. M., I. Bruckental, S. Zamwell, and A. Arieli. 2002. Effect of abomasally infused casein on post-ruminal digestibility of total non-structural carbohydrates and milk yield and composition in dairy cows. Anim. Sci. 74:347-355.

Al-Dehneh, A., J. T. Huber, R. Wanderley, C. B. Theurer, M. Pessarakli, and D. DeYoung. 1997. Incorporation of recycled urea N into ruminal bacteria flowing to the small intestine of dairy cows fed a high-grain or high-forage diet. Anim. Feed Sci. Technol. 68:327-338.

Allen, M. S. 2000. Effects of diet on short-term regulation of feed intake by lactating dairy cattle. J. Dairy Sci. 83:1598-1624.

Allison, M. J. 1978. Production of branched-chain volatile fatty acids by certain anaerobic bacteria. Appl. Environ. Microbiol. 35:872-877.

Andries, J. I., F. X. Buysse, D. L. De Brabander, and B. G. Cottyn. 1987. Isoacids in ruminant nutrition: Their role in ruminal and intermediary metabolism and possible influences on performances-A review. Anim. Feed Sci. Technol. 18:169-180.
AOAC. 1990. Official Methods of Analysis. Vol. I, 15th ed. Association of Official Analytical Chemists, Arlington, VA.

Attwood, G. T., A. V. Klieve, D. Ouwerkerk, and B. K. C. Patel. 1998. Ammonia-hyperproducing bacteria from New Zealand ruminants. Appl. Environ. Microbiol. 64:1796-1804.

Bateman, H. G., II, J. H. Clark, R. A. Patton, C. J. Peel, and C. G. Schwab. 2001. Accuracy and precision of computer models to predict passage of crude protein and amino acids to the duodenum of lactating cows. J. Dairy Sci. 84:649-664.

Beede, D. K., J. D. Ferguson, R. D. Shaver, J. T. Huber, and C. E. Polan. 1994. Study examines animal-marine protein blend use in cow diets. Feedstuffs 66:1-6.

Bremner, J. M., and D. R. Keeney. 1965. Steam distillation methods for determination of ammonium, nitrate, and nitrite. Anal. Chim. Acta 32:485-495.

Broderick, G. A. 2003. Effects of varying dietary protein and energy levels on the production of lactating dairy cows. J. Dairy Sci. 86:1370-1381.

Cameron, M. R., T. H. Klusmeyer, G. L. Lynch, J. H. Clark, and D. R. Nelson. 1991. Effects of urea and starch on rumen fermentation, nutrient passage to duodenum, and performance of cows. J. Dairy Sci. 74:1321-1336.

Castillo, A. R., E. Kebreab, D. E. Beever, J. H. Barbi, J. D. Sutton, H. C. Kirby, and J. France. 2001. The effect of protein supplementation on nitrogen utilization in lactating dairy cows fed grass silage diets. J. Anim. Sci. 79:247-253.

Chan, S. C., J. T. Huber, C. B. Theurer, Z. Wu, K. H. Chen, and J. M. Simas. 1997. Effects of supplemental fat and protein source on ruminal fermentation and nutrient flow to the duodenum in dairy cows. J. Dairy Sci. 80:152-159.

Chaney, A. L., and E. P. Marbach. 1962. Modified reagents for determination of urea and ammonia. Clin. Chem. 8:130-132.

Christensen, R. A., M. R. Cameron, T. H. Klusmeyer, J. P. Elliott, J. H. Clark, D. R. Nelson, and Y. Yu. 1993. Influence of amount and degradability of dietary protein on nitrogen utilization by dairy cows. J. Dairy Sci. 76:3497-3513.

Clark, J. H., and C. L. Davis. 1980. Some aspects of feeding high producing dairy cows. J. Dairy Sci. 63:873-885.

Clark, J. H., T. H. Klusmeyer, and M. R. Cameron. 1992. Microbial protein synthesis and flows of nitrogen fractions to the duodenum of dairy cows. J. Dairy Sci. 75:2304-2323.

Cotta, M. A., and J. B. Russell. 1982. Effects of peptides and amino acids on efficiency of rumen bacterial protein synthesis in continuous culture. J. Dairy Sci. 65:226-234.

Cunningham, K. D., M. J. Cecava, and T. R. Johnson. 1994. Flows of nitrogen and amino acids in dairy cows fed diets containing supplemental feather meal and blood meal. J. Dairy Sci. 77:3666-3675.

Cunningham, K. D., M. J. Cecava, T. R. Johnson, and P. A. Ludden. 1996. Influence of source and amount of dietary protein on milk yield by cows in early lactation. J. Dairy Sci. 79:620-630.

Degussa Corp. 2001. AMINO Dat 2.0. Degussa Corporation, Feed Additives, Kennesaw, GA.

Frank, B., and C. Swensson. 2002. Relationship between content of crude protein in rations for dairy cows and milk yield, concentration of urea in milk, and ammonia emissions. J. Dairy Sci. 85:1829-1838.

Hoover, W. H., and S. R. Stokes. 1991. Balancing carbohydrates and proteins for optimum rumen microbial yield. J. Dairy Sci. 74:3630-3644.

Hungate, R. E. 1966. Conversions of nitrogenous materials. Pages 281-328 in The Rumen and Its Microbes. Academic Press Inc., New York, NY.

Huntington, G. B. 1997. Starch utilization by ruminants: From basics to the bunk. J. Anim. Sci. 75:852-867.

Hvelplund, T., and J. Madsen. 1996. Protein utilization in ruminants. Pages 83-93 in Proc. 7th Intl. Symp. Prot. Met. Nutr. Vale de Santarem, Portugal. EAAP, The Netherlands. National Institute of Animal Science, Foulum, Denmark.

Ipharraguerre, I. R. 2004. Nutritional strategies for optimizing nitrogen utilization by dairy cows. Ph.D. Thesis, Univ. of Illinois, Urbana. 
Ipharraguerre, I. R., and J. H. Clark. 2005a. Impacts of the source and amount of crude protein on the intestinal supply of nitrogen fractions and performance of dairy cows. J. Dairy Sci. 88 (E. Suppl.):E22-E37.

Ipharraguerre, I. R., and J. H. Clark. 2005b. Varying protein and starch in the diet of dairy cows. II. Effects on performance and nitrogen utilization for milk production. J. Dairy Sci. 88:25662570.

Jonker, J. S., R. A. Kohn, and J. High. 2002. Dairy herd management practices that impact nitrogen utilization efficiency. J. Dairy Sci. 85:1218-1226.

Kartchner, R. J., and B. Theurer. 1981. Comparison of hydrolysis methods used in feed, digesta, and fecal starch analysis. J. Agric. Food Chem. 29:8-11.

Klusmeyer, T. H., G. L. Lynch, J. H. Clark, and D. R. Nelson. 1991. Effects of calcium salts of fatty acids and protein source on ruminal fermentation and nutrient flow to duodenum of cows. J. Dairy Sci. 74:2206-2219.

Klusmeyer, T. H., R. D. McCarthy, Jr., J. H. Clark, and D. R. Nelson. 1990. Effects of source and amount of protein on ruminal fermentation and passage of nutrients to the small intestine of lactating cows. J. Dairy Sci. 73:3526-3537.

Kohn, R. A., Z. Dou, J. D. Ferguson, and R. C. Boston. 1997. A sensitivity analysis of nitrogen losses from dairy farms. J. Environ. Manage. 50:417-428.

Kröber, T. F., D. R. Külling, H. Menzi, F. Sutter, and M. Kreuzer. 2000. Quantitative effects of feed protein reduction and methionine on nitrogen use by cows and nitrogen emissions from slurry. J. Dairy Sci. 83:2941-2951.

Leonardi, C., M. Stevenson, and L. E. Armentano. 2003. Effect of two levels of crude protein and methionine supplementation on performance of dairy cows. J. Dairy Sci. 86:4033-4042.

Littell, R. C., G. A. Milliken, W. W. Stroup, and R. D. Wolfinger. 1996. SAS system for mixed models. SAS Institute Inc., Cary, NC.

Lobley, G. E. 2002. Protein turnover-what does it mean for animal production? Pages 1-15 in Proc. Symp. Amino Acids: Milk, Meat, and More. H. Lapierre and D. R. Ouellet, ed. Quebec, Canada. Can. Soc. Anim. Sci.

Loerch, S. C., L. L. Berger, D. Gianola, and G. C. Fahey, Jr. 1983. Effect of dietary protein source and energy level on in situ nitrogen disappearance of various protein sources. J. Anim. Sci. 56:206216.

Ludden, P. A., T. L. Wechter, and B. W. Hess. 2002. Effects of oscillating dietary protein on ruminal fermentation and site and extent of nutrient digestion in sheep. J. Anim. Sci. 80:3336-3346.

Lynch, G. L., T. H. Klusmeyer, M. R. Cameron, J. H. Clark, and D. R. Nelson. 1991. Effects of somatotropin and duodenal infusion of amino acids on nutrient passage to duodenum and performance of dairy cows. J. Dairy Sci. 74:3117-3127.

Mansfield, H. R., and M. D. Stern. 1994. Effects of soybean hulls and lignosulfonate-treated soybean meal on ruminal fermentation in lactating dairy cows. J. Dairy Sci. 77:1070-1083.

Marini, J. C., and M. E. Van Amburgh. 2003. Nitrogen metabolism and recycling in Holstein heifers. J. Anim. Sci. 81:545-552.

McCarthy, R. D., Jr., T. H. Klusmeyer, J. L. Vicini, J. H. Clark, and D. R. Nelson. 1989. Effects of source of protein and carbohydrate on ruminal fermentation and passage of nutrients to the small intestine of lactating cows. J. Dairy Sci. 72:2002-2016.

Merchen, N. R. 1988. Digestion, absorption, and excretion in ruminants. Pages 172-201 in The Ruminant Animal. Digestive Physiology and Nutrition. D. C. Church, ed. Waveland Press, Inc., Prospect Heights, IL.

Moore, S. 1963. On the determination of cystine as cysteic acid. J. Biol. Chem. 238:235-237.

Morrison, M. 2000. The microbial ecology and physiology of ruminal nitrogen metabolism. Pages 99-114 in Ruminant Physiology: Digestion, Metabolism, Growth and Reproduction. P. B. Cronjé, ed. CABI Publishing, New York, NY.

National Research Council. 1985. Ruminant Nitrogen Usage. Natl. Acad. Sci., Washington, DC.

National Research Council. 2001. Nutrient Requirements of Dairy Cattle. 7th rev. ed. Natl. Acad. Sci., Washington, DC.
Nocek, J. E., and J. B. Russell. 1988. Protein and energy as an integrated system. Relationship of ruminal protein and carbohydrate availability to microbial synthesis and milk production. J. Dairy Sci. 71:2070-2107.

Noftsger, S., and N. R. St-Pierre. 2003. Supplementation of methionine and selection of highly digestible rumen undegradable protein to improve nitrogen efficiency for milk production. J. Dairy Sci. 86:958-969.

Oba, M., and M. S. Allen. 2003. Effects of corn grain conservation method on ruminal digestion kinetics for lactating dairy cows at two dietary starch concentrations. J. Dairy Sci. 86:184-194.

Oldham, J. D. 1984. Protein-energy interrelationships in dairy cows. J. Dairy Sci. 67:1090-1114.

O'Mara, F. P., J. J. Murphy, and M. Rath. 1998. Effect of amount of dietary supplement and source of protein on milk production, ruminal fermentation, and nutrient flows in dairy cows. J. Dairy Sci. 81:2430-2439.

Ørskov, E. R. 1992. Protein Nutrition in Ruminants. 2nd ed. Academic Press, Inc., San Diego, CA.

Overton, T. R., M. R. Cameron, J. P. Elliott, J. H. Clark, and D. R. Nelson. 1995. Ruminal fermentation and passage of nutrients to the duodenum of lactating cows fed mixtures of corn and barley. J. Dairy Sci. 78:1981-1998.

Owens, F. N., and A. L. Goetsch. 1988. Ruminal fermentation. Pages 145-171 in The Ruminant Animal. Digestive Physiology and Nutrition. D. C. Church, ed. Waveland Press, Inc., Prospect Heights, IL.

Reilly, K., V. R. Carruthers, and G. T. Attwood. 2002. Design and use of $16 \mathrm{~S}$ ribosomal DNA-directed primers in competitive PCRs to enumerate proteolytic bacteria in the rumen. Microb. Ecol. 43:259-270.

Reynal, S. M., and G. A. Broderick. 2003. Effects of feeding dairy cows protein supplements of varying ruminal degradability. J. Dairy Sci. 86:835-843.

Reynal, S. M., G. A. Broderick, S. Ahvenjärvi, and P. Huhtanen. 2003. Effect of feeding protein supplements of differing degradability on omasal flow of microbial and undegraded protein. J. Dairy Sci. 86:1292-1305.

Reynolds, C. K., J. D. Sutton, and D. E. Beever. 1997. Effects of feeding starch to dairy cattle on nutrient availability and production. Pages 105-133 in Recent Advances in Animal Nutrition. P.C. Garnsworthy and J. Wiseman, ed. Nottingham, UK.

Richards, C. J., A. F. Branco, D. W. Bohnert, G. B. Huntington, M. Macari, and D. L. Harmon. 2002. Intestinal starch disappearance increased in steers abomasally infused with starch and protein. J. Anim. Sci. 80:3361-3368.

Rulquin, H., and R. Vérité. 1993. Amino acid nutrition in dairy cows: Production effects and animal requirements. Pages 55-77 in Recent Advances in Animal Nutrition. P. C. Garnsworthy and D. J. A. Cole, ed. Nottingham University Press, Nottingham, UK.

Santos, F. A. P., J. E. P. Santos, C. B. Theurer, and J. T. Huber. 1998. Effects of rumen-undegradable protein on dairy cow performance: A 12-year literature review. J. Dairy Sci. 81:3182-3213.

Santos, J. E. P., J. T. Huber, C. B. Theurer, L. G. Nussio, M. Tarazon, and F. A. P. Santos. 1999. Response of lactating dairy cows to steam-flaked sorghum, steam-flaked corn, or steam-rolled corn and protein sources of differing degradability. J. Dairy Sci. $82: 728-737$

SAS Institute. 2000. SAS System for Windows. Release 8.1 (TS1 MO). SAS Institute, Inc. Cary, NC.

Satter, L. D. 1986. Protein supply from undegraded dietary protein. J. Dairy Sci. 69:2734-2749.

Schwab, C. G., R. S. Ordway, and N. L. Whitehouse. 2003. Amino acid balancing in the context of MP and RUP requirements. Pages 25-34 in Proc. Four-State Applied Nutrition and Management Conference. LaCrosse, WI. Midwest Plan Service, Iowa State University, Ames.

Sloan, B. K. 1997. Developments in amino acid nutrition of dairy cows. Pages 167-198 in Recent Advances in Animal Nutrition. P. C. Garnsworthy and J. Wiseman, ed. Nottingham University Press, Nottingham, UK.

Stern, M. D., L. M. Rode, R. W. Prange, R. H. Stauffacher, and L. D. Satter. 1983. Ruminal protein degradation of corn gluten meal 
in lactating dairy cattle fitted with duodenal T-type cannulae. J. Anim. Sci. 56:194-205.

Stokes, S. R., W. H. Hoover, T. K. Miller, and R. Blauweikel. 1991. Ruminal digestion and microbial utilization of diets varying in type of carbohydrates and protein. J. Dairy Sci. 74:871-881.

St-Pierre, N. R., and C. S. Thraen. 1999. Animal grouping strategies, sources of variation, and economic factors affecting nutrient balance on dairy farms. J. Dairy Sci. 82(Suppl. 2):72-82.

Supelco, Inc. 1975. GC Separation of VFA C2-C5. Tech. Bull. 749D. Supelco, Inc., Bellefonte, PA

Van Soest, P. J., J. B. Robertson, and B. A. Lewis. 1991. Methods for dietary fiber, neutral detergent fiber, and nonstarch polysaccharides in relation to animal nutrition. J. Dairy Sci. 74:35833597.

Voelker, J. A., and M. S. Allen. 2003. Pelleted beet pulp substituted for high-moisture corn. 2. Effects on digestion and ruminal digestion kinetics in lactating dairy cows. J. Dairy Sci. 86:3553-3561.
Waltz, D. M., M. D. Stern, and D. J. Illg. 1989. Effect of ruminal protein degradation of blood meal and feather meal on the intestinal amino acid supply. J. Dairy Sci. 72:1509-1518.

Williams, C. H., D. J. David, and O. Iismaa. 1962. The determination of chromic oxide in faeces samples by atomic absorption spectrophotometry. J. Agric. Sci. (Camb.) 59:381-385.

Wohlt, J. E., J. H. Clark, and F. S. Blaisdell. 1978. Nutritional value of urea versus preformed protein for ruminants. II. Nitrogen utilization by dairy cows fed corn based diets containing supplemental nitrogen from urea and/or soybean meal. J. Dairy Sci. 61:916-931.

Wu, Z., and L. D. Satter. 2000. Milk production during the complete lactation of dairy cows fed diets containing different amounts of protein. J. Dairy Sci. 83:1042-1051.

Zinn, R. A., and F. N. Owens. 1986. A rapid procedure for purine measurement and its use for estimating net ruminal protein synthesis. Can. J. Anim. Sci. 66:157-166. 